\title{
HABLEMOS DE ÁNGELES CALVOS, DEMONIOS PELONES Y FIGURAS GROTESCAS EN LA ESCULTURA BARROCA GALLEGA
}

\author{
LET US SPEAK OF BALD ANGELS, HAIRLESS DEMONS AND GROTES- \\ QUE FIGURES IN GALICIAN BAROQUE SCULPTURE
}

José Manuel López Vázquez *
Universidad de Santiago de Compostela

ABSTRACT: The unusual bald angels depicted in the interior of the sounding board of the pulpit on the Gospel side of the Monastery of San Martiño Pinario in Santiago de Compostela are the starting point to undertake an iconographical study of the representation of demons in Galician Baroque sculpture, primarily in that found in Santiago de Compostela. In this analysis I go beyond the mere identification of its characteristic attributes in order to try to reconstruct the contents that they could communicate within their cultural context. In order to do so, I turn to sources derived from sacred and profane literature, as well as to Neostoicism as the prevailing trend in Spanish Catholicism of the Counter-Reformation. Finally, considering the fact that we are dealing with works of art whose form must therefore also be interrogated as a possible transmitter of emphatic contents, instead of analyzing them only as simple products of Baroque style, I stress their stylistic mode, especially, the grotesque one that was used in the majority of the examples. Furthermore, the accumulation of new meanings gleaned as a result of the mode's analysis allows me to interpret important works of sculpture, such as two of the reliefs of Pinario's main altarpiece: the Miracles of the Child and of the Pine Tree, from a distinctive and more enriching perspective, such as

KEYWORDS: Iconography, Angels, Demons, Stylistic Mode, Neostoicism

RESUMEN: La inusual representación de unos ángeles calvos en el interior del tornavoz del púlpito de evangelio del monasterio compostelano de San Martiño Pinario es el punto de partida para un estudio iconográfico de la representación del demonio en la escultura barroca gallega y, fundamentalmente, en la compostelana. En nuestro análisis no nos quedamos en el mero reconocimiento de los atributos que lo caracterizan, sino que, además, tratamos de reconstruir los contenidos que estos podían trasmitir en su contexto cultural, para lo cual acudimos a fuentes de literatura sacra y profana y al neoestoicismo como corriente preponderante en el catolicismo español postridentino. Finalmente, teniendo en cuenta que estamos ante obras de arte y que, por consiguiente, su forma también debe ser interrogada como posible trasmisora de contenidos enfáticos, en vez de analizarlas solo como obras de estilo barroco, hacemos hincapié en su modo estilístico, y particularmente, en el grotesco, en el que, en su mayoría, fueron plasmadas. Este incremento de significados a través del análisis del modo nos permite, además, interpretar con una perspectiva distinta y más enriquecedora obras importantes en dicha escultura como son los relieves de los milagros del niño y del pino del retablo mayor de Pinario.

PALABRAS CLAVES: Iconografía, Ángeles, Demonios, Modo estilístico, Neoestoicismo.

Fecha de recepción: 8-8-2014 / Fecha de aceptación: 20-10-2014

\footnotetext{
Este estudio está vinculado con el Grupo de investigación Iacobus GI-1907 y fue realizado dentro del marco de los proyectos de investigación: «Encuentros, intercambios y presencias en Galicia entre los siglos XVI y XX», financiado por el Ministerio de Innovación y Ciencia MICIINHAR201 1-22899. Y "Programa de Consolidación e Estructuración de Unidades de Investigación Competitivas GRC2013-036» y "Proyecto de Consolidación e estructuración. REDES. R2014/024 Proxectos Plan Galego IDT» Ambos financiados por la Xunta de Galicia. Consellería de Educación
} 


\section{ÁNGELES CALVOS EN EL PÚLPITO DEL EVANGELIO DE SAN MARTIÑO PINARIO DE SANTIAGO}

La banda sonora de mi más tierna infancia está rallada de tanto escuchar a Antonio Machín pidiendo al pintor, que "pinta con amor", que pintase angelitos negros. Aproximadamente unos 215 años antes, los escultores del taller de Miguel de Romay -siguiendo muy posiblemente las directrices del mentor del programa iconográfico del conjunto del tabernáculo y púlpitos de la iglesia compostelana del monasterio benedictino de San Martiño Pinario- ya habían reivindicado a angelitos, no negros, sino calvos [fig 1]; aunque ellos lo hicieron con tanta discreción que muy pocos, si exceptuamos a los predicadores que se subían al púlpito del lado de evangelio y miraban hacia el interior de su tornavoz, los podían ver y, de hecho, todavía hoy son muy pocos los compostelanos que tienen noticia de ellos.

No hay duda de que estos angelitos son calvos, pues lo son hasta el punto, que incluso podríamos llegar a entender, aunque no disculpar, que un ignorante no dudase en tildarlos de pelones; sobre todo si tomamos en consideración que su calvicie integral resulta todavía más obvia y significativa, al compararlos con los que los mismos escultores tallaron en el interior del tornavoz del púlpito de la epístola [fig. 2], pues en este caso, a todos ellos, excepto uno que también es limpio de pelo, los representaron con el característico peinado del taller, y más concretamente de Domingo de Romay, en el que los cabellos están pegados a la cabeza formando un triangulo sobre la frente. Desde luego, ver representados a ángeles calvos, pueden sorprender y llevar a error a los que andan por la vida



Fig. 1. Taller de Miguel de Romay, Ángeles del tornavoz del púlpito del evangelio. Santiago de Compostela, San Martiño Pinario.

como el Acertador de El Criticón Gracián, deduciendo en las personas comportamientos a partir de las peculiaridades con que la naturaleza las señaló:

Era este [el acertador] uno de los raros personajes que se encuentran en el vario viaje de la vida, de tan extraña habilidad, que él a todos cuantos encontraba, les iba adevinando el suceso de su vida y el paradexo de ella. Iban atónitos nuestros peregrinos, oyéndole adivinar con tanto acierto. Toparon de los primeros uno de muy mal gesto, y al punto dixo:

- Déste no hay que haga dar buen hecho.

Y no se engañó. De un tuerto pronosticó, que no haría cosa a buen ojo y acertó. A un corcovado le ad[e]vinó sus malas inclinaciones; a un coxo los malos passos en que andaba, y a un çurdo sus malas mañas; a un calvo lo pelón y a un ceceoso lo mal hablado. A todo hombre señalado de la naturaleza, señalaba el con el dedo, diziéndoles se guardasen (Gracián, 1984: 592-593). ${ }^{1}$

1. En la literatura de perfección sacerdotal encontramos textos semejantes en los que se justificaba, a partir de la cita del Levítico 21:17 «el hombre que tuviere mácula, no ofrecerá panes a Dios», que los que que tuviesen 




Fig. 2. Taller de Miguel de Romay, Ángeles del tornavoz del púlpito de la epístola. Santiago de Compostela, San Martiño Pinario.

Es cierto que hay calvos pelones, pues pelón «se dice del que no tiene medios ni caudal: y también del que es miserable y cuitado" (Dic. Aut.). Como también lo es que hay pelones, literal y metafóricamente, con mucho pelo ${ }^{2}$. Unos y otros, en tanto en cuanto pelones, son tan miserables y cuitados como el propio Mundo, que «es pelón con los que le sirven" (Aguado, 1629: 392). Además, pelón «se puede llamar al que es vicioso y pecador» (Puente, 1612: 358), pues:

También los cabellos son los adornos del rostro y de la cabeza y causa en los varones una venerable hermosura. Por lo cual en la divina Escritura son símbolo de las virtudes. Y así con harta propiedad se llama nación pelada adonde en algún tiempo floreció el Reino militante de la Iglesia, el estado religioso y, las heroicas virtudes, y después se agostó todo, porque la mala vida irritó la ira de Dios, y les despojó de tales joyas. Y así añade los Interpretes $A$ las gentes que peló Satanás. Pelón llamamos al pobre, y pelar despojar a uno de su dinero. Y pues solo la virtud merece el nombre de riqueza, con más propiedad se llama pelón el vicioso, y pelado al que el demonio pone en tan miserable estado (Puente, 1612: 92).

Por mucha intención sarcástica que le pudiéramos atribuir a quien ideó el programa y a los escultores que lo plasmaron, jamás podríamos llegar a la conclusión de que, para ellos, algunos ángeles son «miserables y cuitados» que son "gentes que peló Satanás» para convertirlos en viciosos pecadores. Pues quien esto mantuviera, lo haría a conciencia de estar cometiendo una herejía y, por lo tanto, pecando mortalmente, lo que lo abocaría indefectiblemente al infierno, algo que, en el siglo XVIII, nadie se tomaba a broma en España.

Hipotéticamente podría caber la posibilidad de que estos ángeles, en realidad no representasen a tales, sino al demonio, que sí es miserable, cuitado, pecador, vicioso y, por lo tanto, pelón. El cual para engañar a los hombres puede tomar las más diversas apariencias. La literatura religiosa nos habla en este sentido que él puede aparecerse no ya como ángel de luz, bueno o de la guarda, sino incluso como el propio Jesucristo, la Virgen o algún santo, sea varón o hembra. Y es que puede adquirir aspecto humano de cualquier sexo y raza, desde mozo galán hasta moza garrida, siendo frecuente que se aparezca como abrasado, chamuscado, moro, mulato o etíope, y ejercer cualquier estatus laico, desde gañán a caballero, o eclesiástico, desde sacerdote secular o regular hasta Papa, o cualquier oficio, desde gañán hasta rector -aunque el que tengo

defectos físicos, no podrían ser consagrados como sacerdotes: «La razón figural desto era (como dize santo Tomás) porque las máculas, defectos corporales, de que los sacerdotes habían de carecer, significavan diversos vicios, y pecados, de que devían estar agenos" (Pacheco, 1611: 103v). Este autor relata a continuación los vicios y pecados correspondientes a los defectos especifícados en el Levítico 21:18-20.

2. "Gente de pelo. En estilo familiar se llama la que tiene conveniencias, dinero u hacienda» (Dic. Aut.)

IMAGO, NÚM. 6, 20I4, 39-64 
documentado bibliográficamente, aunque parezca mentira, visto lo visto, no sea de universidad, sino solo de colegio de jesuitas (Cienfuegos, 1726: 565-566)- pasando por el de peregrino a Santiago (Navarro, 1631: 32-33). También puede tomar apariencia de animal real o fantástico: desde serpiente, dragón, grifo, león, toro, murciélago, ganso, etc., hasta la genérica de una bestia terrible. Ahora bien, aunque en la literatura religiosa e incluso en la teatral, el demonio pueda metamorfosearse en todas estas apariencias, debemos tener en cuenta que, en nuestro caso, estamos interpretando obras escultóricas, las cuales carecen del desarrollo temporal que poseen aquellas, en las que el demonio siempre se manifiesta, antes o después, como tal. Las esculturas, por el contrario, tienen un carácter de instantaneidad, que hace que su significado dependa, entre otras muchas, principalmente dos cosas: una, el contexto que exige, un determinado, decoro, esto es: lo que es apropiado o no al lugar-y lógicamente el tornavoz de un púlpito no es un contexto apropiado para la representación de demonios disfrazados de ángeles-; y, dos, de las propias limitaciones semánticas del medio técnico empleado, en este caso la escultura, que hace que de alguna manera se deban añadir signos, para que su representación no dé lugar al engaño del fiel. Para este fin, el artista debe tener en cuenta el género, quien dictará el modo de representación conforme a la tradición influyendo este incluso decisivamente en el estilo de la obra-, como ya decía Interián:

Añado aquí, que aun cuando se pinta al
Demonio (el cual, como dice el Apóstol, se
transforma en Ángel de Luz) en figura de
Ángel Bueno o de algún Santo o lo que es
peor, en figura del mismo Jesu-Cristo, lo
que asegura haber acontecido el autor de
la vida de S. Martín; hacen muy bien los pintores cuerdos en ponerle alguna señal o distintivo, con que fácilmente se manifieste, que aquella imagen no es de Cristo, ni algún ángel, o santo, sino del Demonio: para denotar esto, le ponen en la cabeza unos pequeños cuernos, u orejas de liebre, o largas y retorcidas uñas en las manos, o bien le pintan con pie de caballo o le añaden otra cosa semejante: no porque el Demonio cuando se manifiesta a alguno en la forma y figura corpórea, que él ha tomado y fingido para engañarle y seducirle, no tenga poder para apartar de si estas señales, sino porque los efectos, que causa en el alma del que le ve, son tales, que si en realidad no quiere ser engañado, con facilidad conocerá la ilusión, singularmente, si es humilde de corazón, ama fervorosamente a Dios, sobre lo cual advierten muchas cosas los Doctores Ascéticos (Interián de Ayala, 1782: 174).

Consecuentemente, como en estos ángeles no encontramos signos que los identifiquen sin lugar a dudas como demonios, debemos interpretarlos como lo que son: ángeles. Y si de peculiaridades físicas, como el Acertador de Gracián, dedujéramos comportamientos morales, diríamos que estos ángeles poseen por naturaleza la misma virtud, que a los humanos les produce la enfermedad conocida como la pelona, que los vuelve «liberales y generosos»:

\footnotetext{
Uno de los mayores indicios de santidad es un dolor de los pecados. ¿Pues quién hay que tantos dolores padezca por sus pecados como el buboso? ¿quiénes son liberales, francos y dadivoso, sino los tales? Nunca el buboso fue pelón ni miserable. De donde así como llamamos por contrario sentido a un negro que va por la calle Juan blanco, y a una mujer pública, Buena mujer, así llamamos a esta santa dolencia, la Pelona, como quien dice liberal y generosa (Hidalgo, 1610:78) $)^{3}$
}

3. Gaspar Lucas Hidalgo, «Diálogos de apacible entretenimiento, que contiene unas Carnestolendas en Castilla. Dividido en tres noches, del Domingo, Lunes y Martes de Antruexo,Procura el autor en este libro entretener al Letor con varias curiosidades de gusto, materia permitida, para recrear penesos cuydados a todo género de gente» (Brusselas, Por Roger Vulpuis, impressor jurado, 1610) 
Hablemos de ángeles calvos, demonios pelones y figuras grotescas en la escultura barroca gallega

En realidad, en cuestión de naturaleza, lo que debemos tener en cuenta es, como dice Critilo, uno de los protagonistas de $E l$ Criticón, que «la razón, en los varones sabios, corrige todos estos pronósticos siniestros» ${ }^{4}$ Por consiguiente, la calvicie de estos ángeles, es una llamada al monje que se sube al púlpito para predicar la palabra de Dios, para que se corrija conforme a razón, y que él sea y actúe como ellos, esto es: que sea liberal y generoso en lo que verdaderamente importa, que es lo sustancial a su alma y a las de los que lo escuchan y que, por el contrario, no se deje tentar por el demonio convirtiéndose en un pelón concupiscente de los bienes o de la vanagloria del mundo:

\begin{abstract}
$\mathrm{Al}$ aficionado a estos bienes le hace ascos la religiosa pobreza, el vestido ordinario, el estrecho aposento, y la humilde cama, y la parca comida, y las alhajas comunes. De aquí se sigue, acomodarse mal a la vida Religiosa [...]. Dificultoso se le hará vivir en Religión al rico de espíritu, y que tiene puesto en las riquezas su amor: mucho tendrá que vencer, hallará a cada paso tropiezos y estorbos en las obligaciones, con que ciñe la santa pobreza. [...] ¿Cómo se puede creer que vencerá un hombre la pasión por el deleite, que esta injerta en la carne, si no ha podido hollar la codicia de las riquezas, que nos caen por fuera? Esta es pues la causa, porque Dios quiere que el Religioso se pele como una paloma, y que no esté como corneja pintada de plumas, porque se crie con humildad y se acomode y ajuste a la vida Evangélica.
\end{abstract}

¿Por mas quiere Dios, le quiten a la paloma las plumas? Porque lo que había de gastar en las plumas, lo gasten en el ser. Sabida cosa es que mientras más atienden a la pluma las aves, menos atienden al ser, y están más consumidas y flacas. Y por esta causa deben llamarse los hidalgos pelones, porque descuidan del ser, y cuidan del pelo, y faltándoles el sustento, con que han de criar sustancia, procuran buena apariencia, y cubren el buen vestido con mucha miseria. Por lo cual dijo el Sabio muy bien [...] mejor es la suerte del buen labrador, que vistiendo paño buriel tiene su casa mantenida, que el hidalgo pelón, que con buena capa muere de hambre. De esta suerte considero yo en las Religiones algunos, que son como los labradores honrados, bien mantenidos en las virtudes, y ejercicios devotos, pobres en lo exterior, más satisfechas las almas del buen sustento, que comen. Otros como hidalgos pelones en lo exterior viven lucidos en sus personas y celdas; pero en lo interior, ayunos del bien, que sustenta; los cuales debajo de buen pelo cubren flaquezas humanas. Quisiera nuestro Señor que sepa pelarse el ave, y que el Religioso se desnude de todo, para que descuidando la apariencia exterior, emplee todas sus mientes en la sustancia del ser (Aguado, 1619: 18).

Precisamente del contexto en que se insertan los ángeles, un pulpito desde el que se enseña la palabra de Dios -y de hecho, ellos la evidencian, en tanto en cuanto confirman una teofanía, pues son en realidad querubines, los cuales están en «la Santidad de las Santidades", de ahí que formen una corona alrededor de una estrella que irradia luz ${ }^{5}$, deduzco la posibilidad de que a través de ellos, no solo se le puede estar diciendo al

4. «Lo primero que observé fue esta disposición de todo el cuerpo, tan derecha, sin que tuerça, a un lado ni a otro.

- Fue el hombre -dixo Artemia- criado para el cielo, y assí crece hazia allá; y en essa material rectitud del cuerpo está simbolizada la del ánimo, con tal correspondencia, que al que le faltó por desgracia la primera sucede con mayor faltarle la segunda.

- Es assi dixo -Critilo- donde quiera que hallamos corvada la disposición, rezelamos también torcida la intención; en descubriendo ensenadas en el cuerpo, tememos haya doblezes en el ánimo; el otro a quien se le anubló alguno de los ojos, también suele cegarse de passión, y lo que es digno de más reparo que nos les tenemos lástima como a los ciegos, sino rezelo que no miran derecho; los coxos suelen tropeçar en el camino de la virtud, y aun echarse a rodar, coxeando la voluntad en los afectos; faltan los mancos en la perfección de las obras, en hazer bien a los demás. Pero la razón, en los varones sabios, corrige todos estos pronósticos siniestros» (Gracián: 1984, 189-190). 5. La estrella con sus rayos es un signo mudo que notifica a Jesús, como los predicadores lo hacen con su discur- 
monje que lo que predica debe estar acompañado con la ejemplaridad de su vida, sino también, que en el modo de la predicación utilice el estilo humilde, dejándose de vana retórica y de plumas floridas y se centre en trasmitir la sustancia evangélica, aunque para ello tenga que descuidar la apariencia exterior y todo su plumaje, reprimiéndose de emplear el estilo sublime, que sin duda le daría más gloria a los ojos del mundo.

\section{FIGURAS GROTESCAS EN LA ESCENA DEL MILAGRO DEL PINO DEL RETABLO MAYOR DE LA IGLESIA DE SAN MARTIÑO PINARIO DE SANTIAGO}

Cuando estos mismos escultores pretendieron representar el demonio, en la escena del Milagro del Pino [fig. 3], lo identificaron con alguno de los signos de los que habla Interián de Ayala. Rivadeneyra cuenta así el episodio:

\footnotetext{
En otro lugar, aviendo asolado un templo de los Gentiles, quiso echar en tierra un alto pino, que allí estava dedicado al demonio. Opusierónsele los Gentiles, y uno dellos más atrevido y agudo, alçando la voz le dixo: si tú tienes tanta confiança en tu Dios, nosotros mismos cortaremos este árbol, con tal que quando cayere, le sostengas, y sustentes con tus ombros. Aceptó el partido. Cortaron el árbol, y ataron al santo Pontífice por los pies para que no pudiese huir: y él como una estatua se astuvo de moverse
}

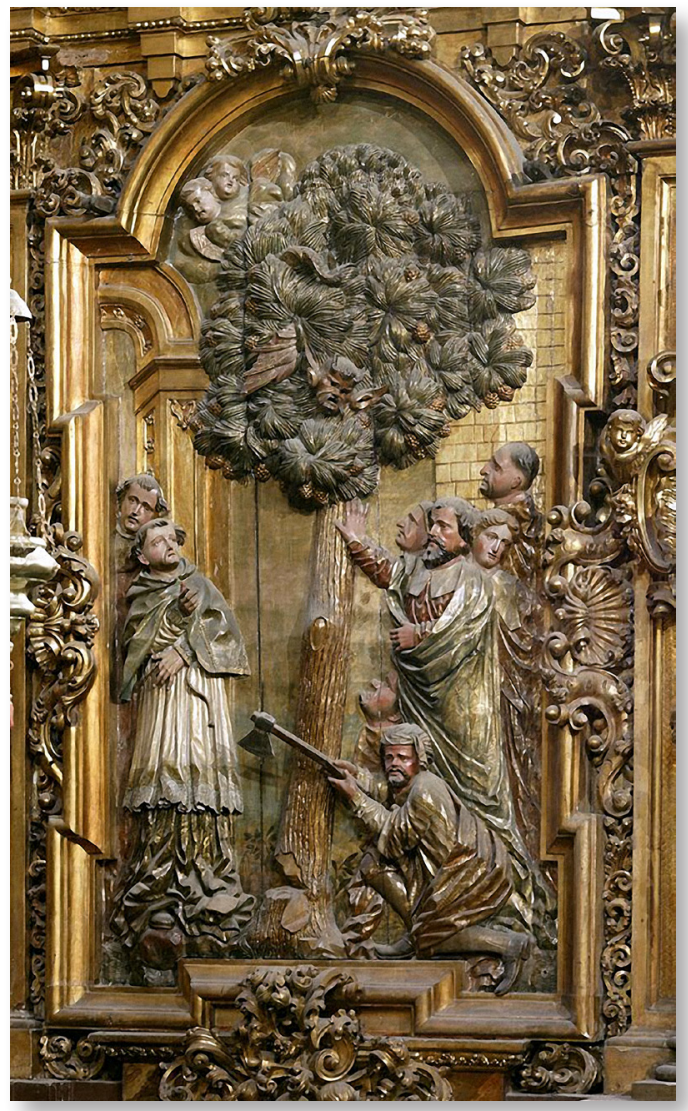

Fig. 3. Taller de Miguel de Romay, Milagro del Pino. Santiago de Compostela, San Martiño Pinario.

con gran seguridad, hasta que inclinándose el árbol, y viniendo con gran ruydo a caer sobre él, sin turbarse alço el braço y hizo la señal de la Cruz, y luego al momento el pino se rebolvió en la parte contraria, y falto poco para que no oprimiesse y matasse a los mismos Gentiles que le avian cortado. Los cuales por un prodigio tan estraño, y tan repentino, alçando las manos, y las vozes al cielo, se rindieron a la voluntad de

so. Véase en este sentido textos como: "Más a mi ver es justo que sepamos, como naciendo nuestro Redentor, es enviado un Ángel a los pastores en Judea, para que se lo haga saber, y a los Magos no fue Ángel, sino una estrella que los guiase y traxese adonde le habían de adorar. Justa providencia del Señor dispuso, que los judíos que usaban de la razón, fuesen avisados por el Ángel que la tiene; y los Gentiles fueron dadas las señales como a infieles. Debéis también notar, que siendo ya nuestro Redentor de edad perfecta, los mismos Apóstoles fueron a predicársele a los Gentiles; y siendo infante, y de tal edad que según ella no podía aún hablar, fue una estrella a notificársele. Todo esto iba conforme a razón, porque en estando ya nuestro Redentor en edad que hablaba era justo que unos predicadores que hablasen diesen noticia de él; y siendo en edad que no hablaba le predicasen los elementos mudos» (Alcuino, 1795: 170) 
san Martín y se convirtieron a Christo (Rivadeneyra, 1616: 771-772).

El demonio, al que está consagrado el pino, aparece, en medio de sus ramas [fig. 4]. Sin embargo, estamos en un momento en que el diablo se ridiculiza, utilizando para ello un modo grotesco, y se representa como un hibrido, con cabeza humana, portando cuernos -que simbolizarían su soberbia, como señala Molanus citando a Job 41, 24-25 (Molanus, 1771: 69)-, pero que, en este caso, son de cabra -con lo que se le tilda, socarronamente, de cornicabra, sodomita e inductor de todo tipo de peca$\mathrm{do}^{6}-$, orejas de asno -su pecado, como el de Midas, es la soberbia ignorante-, alas y cola de dragón -recordando a la bestia apocalíptica a la que remite Molanus, el cual sigue, además, un texto tomado del IV Concilio de Letrán, para señalar que la cola de dragón simboliza la herejía o la fe mendaz (Molanus, 1771: 69) y, precisamente, esta es la que está combatiendo san Martín en el milagro representado-. Además, se le figura calvo -pero con flequillo sobre la frente como las cabras-, capón rancioso, pues, su faz está llena de pliegues ${ }^{7}$, que él ingeniosamente, aprovecha para añadir a los que le circundan la boca un postizo de cuero teñido simulando un largo bigote, de manera que, verdaderamente, solo tiene pelo en la barbilla al igual que las cabras, y, lo que es más significativo, también se le figura bizco, para mostrarnos que es de intención o

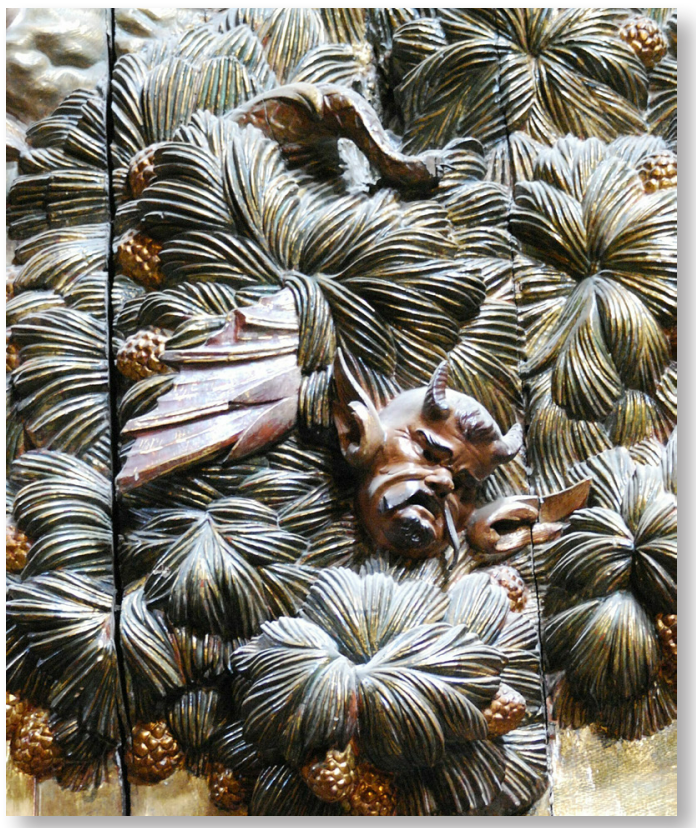

Fig.4. Taller de Miguel de Romay. Detalle del Milagro del Pino. Santiago de Compostela, San Martiño Pinario.

voluntad torcida y un gran engañador ${ }^{8}$. Por último, tiene el ceño fruncido, evidenciando así, inequívocamente que de él «no hay que haga dar buen hecho», como lo que vaticinaba el Acertador de aquel que tenía «muy mal gesto».

Este modo grotesco, se lleva también a las figuras del último término para, de esta manera, ofrecernos su verdadera catadura moral. Así, en el suelo, detrás del leñador, hay un personaje, representado de perfil, que literal y metafóricamente es un cabe-

6. «Cornicabra. Metaphóricamente significa el torpe y ruin consentimiento de galán o marido» (Dic. Aut.). «Ya que tenemos que cosa sea este Dios Pan, assentara mejor lo del sentido literal que el Satyro cornicabra es animal luxurióíisimo y por esso lo recibieron para con el significar al malvado Chan hijo de Noé, que enseñó el pecado contra natura; y por tal deidad bien se entiende el demonio induzidor a todo linaje de pecado» (Pineda, 1606: 45). 7. Recordemos aquel personaje femenino de Torres Villarroel, al que el paso de los años, "la pusieron por su fealdad a dos dedos de ser demonio» y "volviéndose marimacho, y brotó un par de bigotes como un tudesco, repartiendo el semblante entre las fierezas de machorra y los pliegues de capón rancioso» (Torres Villarroel, 1794: 277-278)

8. «Bizco. Lo mismo que bisojo, o el que mira totalmente atravesado» (Dic. Aut.) Por lo tanto, al igual que le ocurrió a uno de los personajes de El criticón que lavó sus ojos en la fuente de los engaños, también a él «se le equivocó la vista de modo que veía lo que no miraba, bizco de intención y de voluntad torcida» (Gracián, 1984: 156). Por otra parte, en la descripción del Engaño, Gracián, dice que tiene «la vista atravesada» (Gracián, 1984, 183) y el demonio es, precisamente, el gran engañador. 




Fig. 5. Taller de Miguel de Romay. Detalle del Milagro del Pino. Santiago de Compostela, San Martiño Pinario.

zudo [fig. 5]. «Cabezudo. En lo literal vale disforme y grande de cabeza. Usase más translaticiamente, y se toma por el terco, porfiado, tenaz, assido a su dictamen, que no se sujeta a la razón, ni opinión de otro» (Dic. Aut.). Y, está claro que él no se sujeta a la opinión de Martín. Por otra parte, a juzgar por lo hundida que tiene la boca, no solo es terco, sino también, mamón de pronunciación?, es decir, que como el ceceoso de Gracián es un mal hablado, e, incluso, también es muy posible que por su forma de proceder no solo sea literalmente un mamón -que chupa, porque no puede masticar-, sino también metafóricamente, pues «Mamón, se llama por alusión a la persona que en su trato y modo de proce-

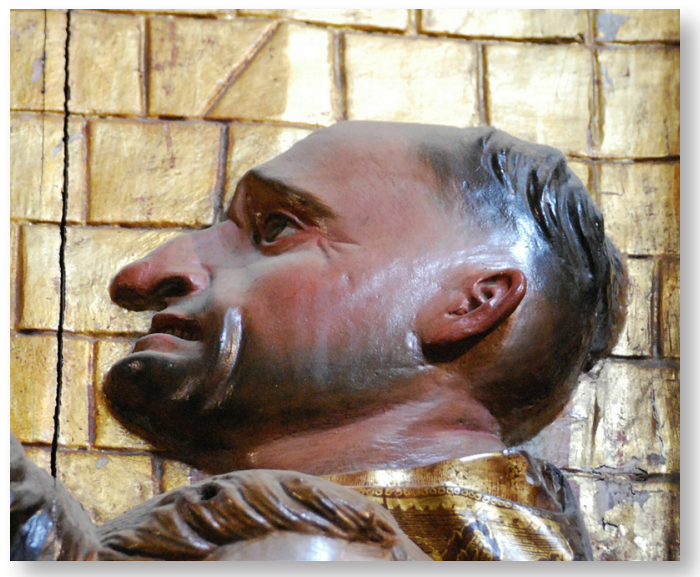

Fig. 6. Taller de Miguel de Romay. Detalle del Milagro del Pino. Santiago de Compostela, San Martiño Pinario.

der, tiene cosas de niño» (Dic. Aut.). Y él está actuando temerariamente como un niño, metiendo la cabeza a ras de suelo entre la gente para, así, poder estar en primera fila y no perder detalle, sin darse cuenta del peligro que semejante acción conlleva, pues no podrá escapar si el pino cae hacia su lado. De pie, en último término, se representa a otro cabezudo, aunque mucho menos que el anterior, el cual, como denota su enorme nariz [fig. 6], se las da de nasudo y por consiguiente de avisado -recordemos: "Hombre narigudo, pocas vezes cornudo, porque la nariz larga es señal de ser avisado el hombre» (Núñez de Guzmán, 1555: 58)-, lo que le lleva a que, precavidamente, se coloque como el más alejado del pino del grupo. Pero también su narizota lo denuncia como embustero ${ }^{10}$. De hecho el es un calvo a traición ya que empieza a calvar por el cogote o cocote ${ }^{11}$. Sin darse cuenta, que al

9. Como «la más antigua de las alcahuetas» que a decir de Quevedo también era «mal asistida de dientes y mamona de pronunciación» (Quevedo, 1987: 205)

10. Por ejemplo, en Gracián, la nariz grande no solo denota sagacidad, sino también engaño: «-Esto ponderaban, cuando vieron assomar por su magestuosa puerta, al cabo de muchas varas de nariz, un hombrecillo de media, que viéndolos admirados les dixo:

-Yo no sé de qué, pues assí como hay hombres de gran coraçón y de gran pecho, yo lo soy de grandes narizes. -Toda gran trompa -dixo Critilo- siempre fue para mí señal de grande trampa.

-Y por qué no de sagacidad? -replicó él-. Pues advertí que con ésta os he de abrir camino; seguidme» (Gracián, 1984: 458).

11. "Calvar a traición. Se dice vulgar y familiarmente de los que empiezan a perder el pelo y descubrir el pellejo 
quedar desamparado por su espalda, puede fácilmente perderse al «dar de cocote» ${ }^{12}$. Lo cual es muy probable por su mala conducta, de la que no hay ninguna duda, teniendo en cuenta que, como el Engaño en El criticón, él "hasta en la nariz tiene corcova» (Gracián, 1984: 183). El personaje principal, el "atrevido y agudo», es un noble que actúa innoblemente intentando manipular el partido o ordalía pactada, empujando con su mano el pino para que caiga sobre san Martín, pero lo único que consigue es que el prodigio resulte todavía más evidente. Como su gesto, es tan obvio, no es preciso que se deforme grotescamente para subrayar su catadura moral y esto es un aviso para que el fiel juzgue a las personas por sus obras, más que por lo que parecen. A su lado, se representa una mujer que, como tal y conforme a la misoginia del momento, actúa desde el sentimiento y no desde la razón, y, consecuentemente, llevada de su sensibilidad y de su falta de confianza en la fe de Martín, se da la vuelta para no ver los desagradables resultados que se producirán al caer el pino sobre él, por lo que, como a las vírgenes necias, los acontecimientos la cogerán desprevenida.

\section{TIPOS VULGARES EN LA ME- DALLA DEL MILAGRO DEL NIÑO DEL RETABLO MAYOR DE LA IGLESIA DE SAN MAR- TIÑO PINARIO DE SANTIAGO}

En frente, al del pino, se representa el milagro de la resurrección de un niño [fig. 7].

Yendo una vez a la ciudad de Chartres huvo de pasar por una aldea que era toda de Gentiles; los quales por la fama del San-

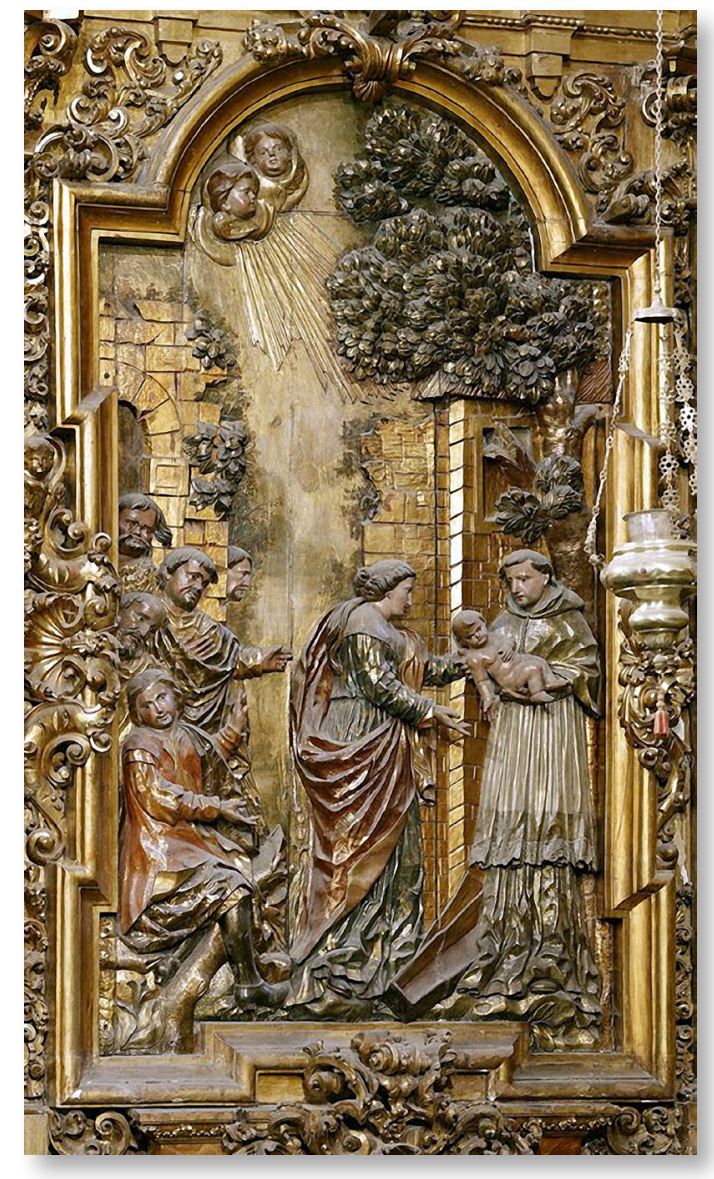

Fig. 7. Taller de Miguel de Romay. Milagro de la resurrección de un niño. Santiago de Compostela, San Martiño Pinario

to salieron todos a verle, y concurrió tanta gente que los campos estaban cubiertos de labradores idólatras $\mathrm{y}$, sin conocimiento de Dios verdadero. Quando los vio el Santo Prelado, enternecíose en gran manera, y con entrañable afecto, poniendo los ojos en el cielo començó a predicarles la palabra de Dios, y combidarlos a la salud eterna, con un sentimiento, y con unas palabras, voz y energía tan grande, que se veía bien que no era él que hablaba sino Dios en él. El qual para dar eficacia a las palabras de San Martín, y confirmarlas con su braço poderoso

por el cogote, manteniéndose el pelo en lo demás de la cabeza»

12. «Dar de cocote es caer de espaldas y metafóricamente se suele decir como predicción y anuncio de que alguno por su mala conducta está próximo a perderse» (Dic. Aut.).

IMAGO, NÚM. 6, 2014, 39-64 
para bien de toda aquella gente rústica, y ciega ordenó que una muger le truxesse allí delante un hijo único, que poco antes se le avía muerto, suplicándole que le restituyese la vida, pues era amigo de Dios, y tan fácilmente lo podía hazer. Juntarónse con los ruegos, y con las lágrimas de la madre, los sollozos, y la intercesión de todo el pueblo, y san Martín juzgando, que aquel milagro sería ocasión, para que se convirtiesen a la Fe de Christo, hizo oración, y le resucitó, y bolvió vivo a su madre (que estaba pasma, y como atónita y fuera de sí de alegría) en presencia de toda aquella gente, que movida de lo que avía visto, alçando un grito al cielo, corrió con grande ímpetu, y se echó a los pies del santo, pidiéndole, que los hiziesse Christianos, quedando el más contento por aver ganado aquellas almas al Señor, que si hubiera conquistado un Reino, o alcançado otra cosa temporal (Rivadeneyra, 1616: 771).

En este caso, para mostrarnos que el pueblo que asiste a milagro, y que ruega a san Martín para que acceda a lo que le pide la madre del niño, es, aunque idólatra, gente de buen corazón, se les representa a través de tipos vulgares, desaliñados e, incluso algunos muy feos, pero no grotescamente deformados como los tozudos e hipócritas representados en el milagro anterior. Con estos tipos vulgares se buscaba representar a rústicos, ya sean gañanes, ya nobles, pues, era creencia generalizada de que ellos eran gente sencilla y sin dobleces, no corrompida por la mentira de la corte. De hecho, el testimonio de gañán, era tenido proverbialmente como verdad irrefutable a través de la sentencia: "no me lo harán creer cuantos aran y cavan ${ }^{13}$. Por otra parte, las tres figuras del primer término, son, si tenemos en cuenta sus vestiduras, hidalgos. Mientras que la del medio es un anciano -que presenta una calva ya considerable- y es un hombre generoso y discreto, como lo demuestra su nariz aguileña ${ }^{14}$ y el que no haga aspavientos-, las otras dos no cabe duda de que son pelones, pero, en este caso, lo son literal, más que metafóricamente, pues no tienen nada de "miserables y cuitados», sino que poseen un natural virtuoso -aunque desperdiciado al no estar educados en la verdadera virtud- como lo evidencian con su gesto de llevarse, uno, la mano derecha al corazón e indicar con la izquierda el milagro y, el otro, de volverse hacia el espectador, en el típico recurso barroco de llamada, insistiéndole en mostrárselo con su mano diestra, avisándole: «mira», mientras que con la izquierda, también, llama su atención hacia él. De este modo, esta persona que, al contrario del anciano, no tenía nada de discreto y no era nada esforzado, sino que era pura vanidad -no tiene barba ${ }^{15}$, y está sentado, sobre un infértil suelo pedregoso 13. «Phrase vulgar para expressar la dificultad que uno tiene en dar assenso y crédito à alguna cosa extravagante ò
irregular, aunque se diga y afirme por cierta y verdadera, y como si la dixera la gente rústica, que como más senci-
lla, y de menos artificio suele decir desnudamente la verdad» (Dic. Aut.). Dicho del cual ya Quevedo se burla en el
Cuento de Cuentos, comentando: «Considere vuesa merced qué letrados o teólogos buscó, sino gañanes» (Quevedo,
1993: 392).
14. La nariz aguileña como denotativa de generosidad la encontramos en El criticón: «-Esso es en los niños -dixo
Critilo-, que en los ya varones más se purgan los excessos de las passiones del ánimo, y assí sale por ellas el viento
de la vanidad, el desvanecimiento, que suele causar vahídos peligrosos y en algunos llega a trastornar el juizio.
Desahógase también el coraçon y evaporándose los humos de la fogosidad con mucha espera, y tal vez a su sombra
se suele dissimular la más picante risa. Ayudan mucho a la proporción del rostro y por poco que se desmanden
afean mucho. Son como el gnomon del relox del alma, que señalan el temple de la condición: las leoninas denotan
el valor, las aguileñas la generosidad, las prolongadas la mansedumbre, la sutiles la sabiduría y las gruesas la nece-
dad» (Gracián, $1984:$ 198). Mientras que como denotativa de discreción la encontramos incluso en el refrán: «El
diablo, antes os la dará [se refiere a la mujer] roma que aguileña» que aparece recogido en El Quijote y en El diablo
Cojuelo.
15. "Hombre de barba. Corresponde a lo mismo que hombre de valor y esforzado, y a hombre de bien y honra-
do» (Dic. Aut) o «Quixadas sin barba no merecen ser honradas. Rf. Que enseña, que assí como por las barbas se 
a caballo de un infructuoso tocón seco- ha empezado a dar fruto y comienza una nueva vida, como lo ha hecho el propio niño, al resucitar. En este sentido podemos reparar en la comparación que ostensiblemente se nos presenta entre el tocón y el féretro, pues ambos dejarán de ser útiles y denotativos de vanidad y muerte. Como también ha empezado una nueva vida el otro hidalgo pelón, pues con su nueva actitud corrige la anterior-apreciemos que tampoco tiene barba- fruto de la necedad a la que estaba abocado por naturaleza -véase su gruesa nariz-, pues su corto entendimiento no es óbice, para que él, en adelante, lo emplee adecuadamente haciendo que su voluntad procure el bien.

\section{DEMONIOS PELONES... Y QUE TIENEN LA LENGUA MUY LARGA}

Alrededor de unos diez años más tarde, el mismo taller volvió a tratar el tema del demonio en el san Miguel que corona el retablo de san Benito [fig. 8]. Su colocación en el lado norte y en lo alto, es el codificado para el capitán del ejército celeste y principal defensor de la Iglesia, pues este es el lado de la oscuridad y la victoria del arcángel, es la de la luz sobre ella. El demonio aparece caracterizado con atributos que ya hemos visto en la representación anterior: las alas y la cola de dragón, las orejas de burro, los cuernos caprinos. Sin embargo, ahora se le representa pelón medio tiñoso, con los dedos de la manos y de los pies en forma de garras -que aquí más que ave de presa tienden a ser de león, pues recordemos que en san Pedro, el demonio es un «león fiero, [que] anda siempre dando bramidos, cercándoos

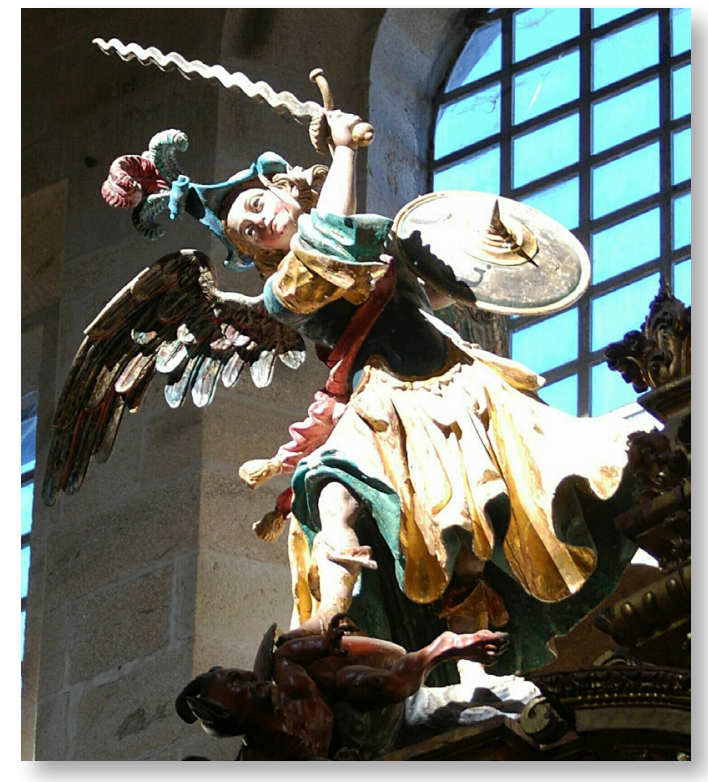

Fig. 8. Taller de Miguel de Romay. san Miguel. Santiago de Compostela, San Martiño Pinario

a todos y buscando a quien hacer pedazos» (1 Pedro 5,8)-, con las que él atrapa a sus víctimas para no soltarlas. Tiene además la piel de color cobrizo tirando a rojo. Este era un color frecuente en la manera de representar al diablo, teniendo en cuenta que el rojo era el color del dragón apocalíptico. Fray Luis de Granada (1584: p. 70) dice que este color significa en él la sangre de los mártires. Miguel de la Vega (1647: 33), refiriéndose concretamente ya al demonio dice que el color rojo "es el fuego que le abrasa». Además, «El cutis pardo y roxo» es el que tiene el demonio que en forma de terrible fiera que ataca «saltando con todo su peso sobre su ombro derecho", a la venerable madre María Ángela Astorch (Zeballos, 1733: 428). Si nos subimos al coro alto, podemos apreciar el bigote teñido y otros rasgos que son muy característicos del diablo, en tanto que son derivados residuales de su tradicional iconografía de grifo: la nariz aguileña, el mentón

entiende el ser hombre, y tener acciones de tal, el que, aunque las tenga, no cumple con las obligaciones de serlo, no merece ser respetado" (Dic. Aut). 


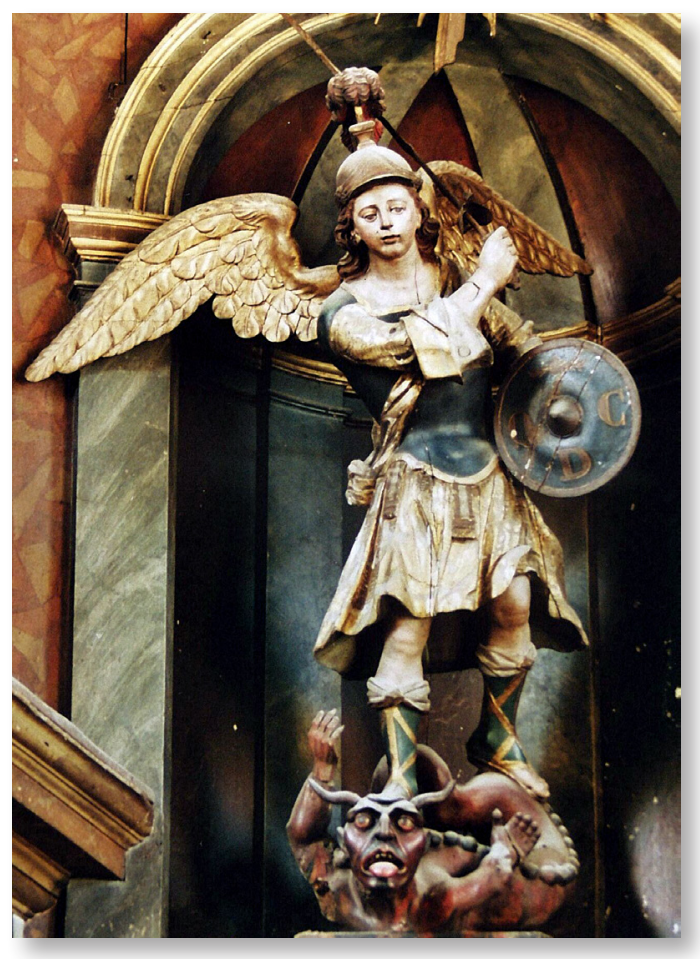

Fig. 9. Anónimo. San Miguel. Santiago de Compostela, San Miguel dos Agros.

prominente y las pupilas de los ojos muy redondas y destacadas.

En este caso, los escultores del taller de Romay, sí se había tomado en serio al diablo, pero, en la imagen del patrón [fig. 9] que preside el retablo mayor de la vecina iglesia parroquial de San Miguel dos Agros, la figura del demonio aparece otra vez totalmente caricaturizada. Más que el color, que ha cambiado con la restauración, aunque podría estar en relación con «el cutis pardo y rojo» de la venerable María de los Ángeles, y que uno de los enormes ojos redon- dos es estrábico -por lo cual no hay duda de que mira torcido-, lo que me interesa destacar es el incremento de su bestialidad, acentuando sus rasgos de dragón a modo de tarasca, y, sobre todo, su mayor gesticulación. En este sentido, el demonio no le está "sacando la lengua" a san Miguel, mostrándole su desprecio ${ }^{16}$, sino que se representa "echando la lengua" de lo mucho que se fatiga trabajando para conseguir sus fines ${ }^{17}$. Sin embargo, llevado de su soberbia, al enseñarle al fiel que la tiene muy $\operatorname{larga}{ }^{18}$, lo que está haciendo es hacerle evidente que él es el máximo "murmurador, perjuro, maldiziente y blasphemo" (Torres, 1607: 157), y como los pecados de la lengua, empezando por las palabras ociosas, terminan por ser los mayores, el fiel debe percatarse que ella es el "portillo y puerta por donde Satanás le hace mayor guerra" (Alamín, 1714: 428) y del que se vale para llevarle infierno, por lo cual el fiel debe atar la suya (Torres, 1607: 157), excepto en la confesión. De hecho hay dos tipos de demonios, el de lengua larga que murmura, perjura, maldice, blasfema y habla con palabras ociosas, como este, y el demonio mudo, que es el que hace que el fiel enmudezca y se guarde pecados en la confesión ${ }^{19}$, como podría ser el de San Martiño.

En el arte rural gallego hay demonios con una lengua más larga que un palmo, los cuales pueden adquirir forma monstruosa, como el atributo de san Miguel de Santa María de Alba (Pontevedra) [fig. 10] o casi humana como el de san Bartolomé de Santa María de Castañeda [fig. 11]. Otros, como el también atributo de san Bartolomé

16. «Sacar la lengua. Phrase que además del sentido recto, significa notar los defecto públicos y mal vistos, que desdicen a la estimación de alguna persona; y assí decimos, No haga V.m. esto porque todos le están sacando la lengua» (Dic. Aut.).

17. «Echar la lengua. Desear con ansia alguna cosa, trabajar y fatigarse por alcanzarla; y regularmente se añade, de un palmo" (Dic. Aut.).

18. Tener la lengua larga significa "ser murmurador, charlante, desvergonzado" (Terreros Pando, 1787: 423). 19. «No sé si avrán notado, que a la muger que dixe arriba, que tenía un palmo de lengua, solo un Demonio la lleva al infierno, y esto a cavallo [...] a esta la llevan dos [...] Pues si aquella la lleva al infierno uno ¿porqué a esta la llevan dos?. Porque a la muger a la que se refiere san Juan, era un Demonio hablador; esta era un Demonio mudo; 


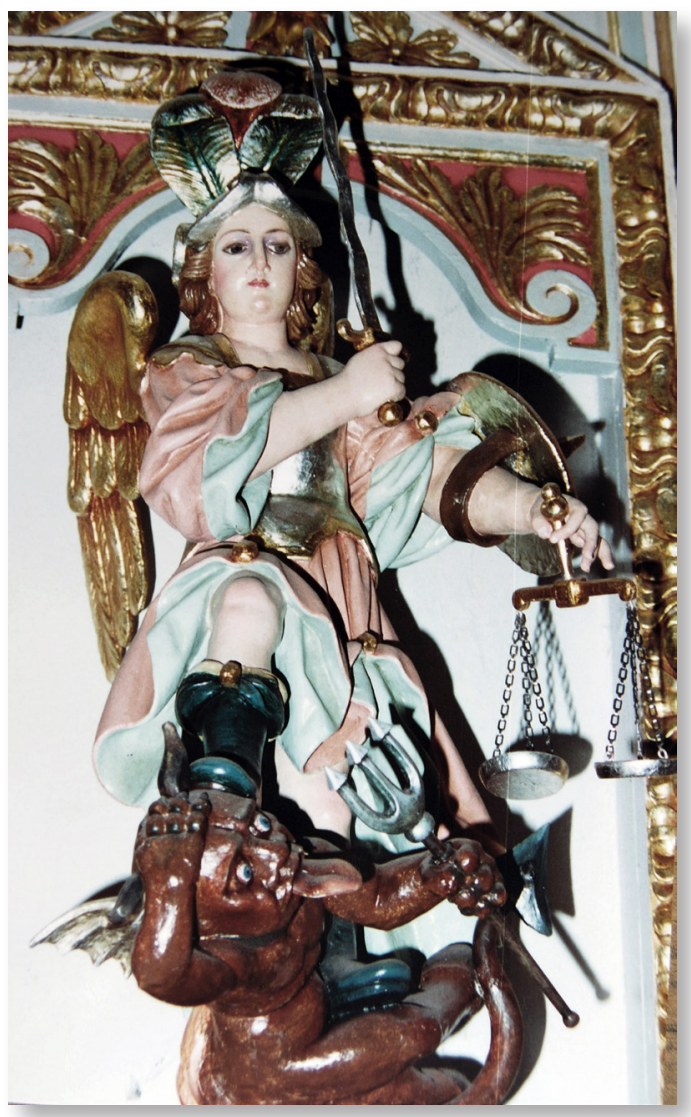

Fig. 10. Anónimo. San Miguel. Pontevedra. Iglesia parroquial Santa María de Alba

de Santa Baia de Curtis [fig. 12], se relamen regodeándose en la murmuración. Contra todos ellos, lo más efectivo es combatir su lengua (san Miguel de Santo Tomé de Lourenzá) [fig. 13], y, todavía mejor, cercenársela, llegando hasta lo más profundo del paladar (san Miguel. San Fiz de Esteiro) [fig. 14].

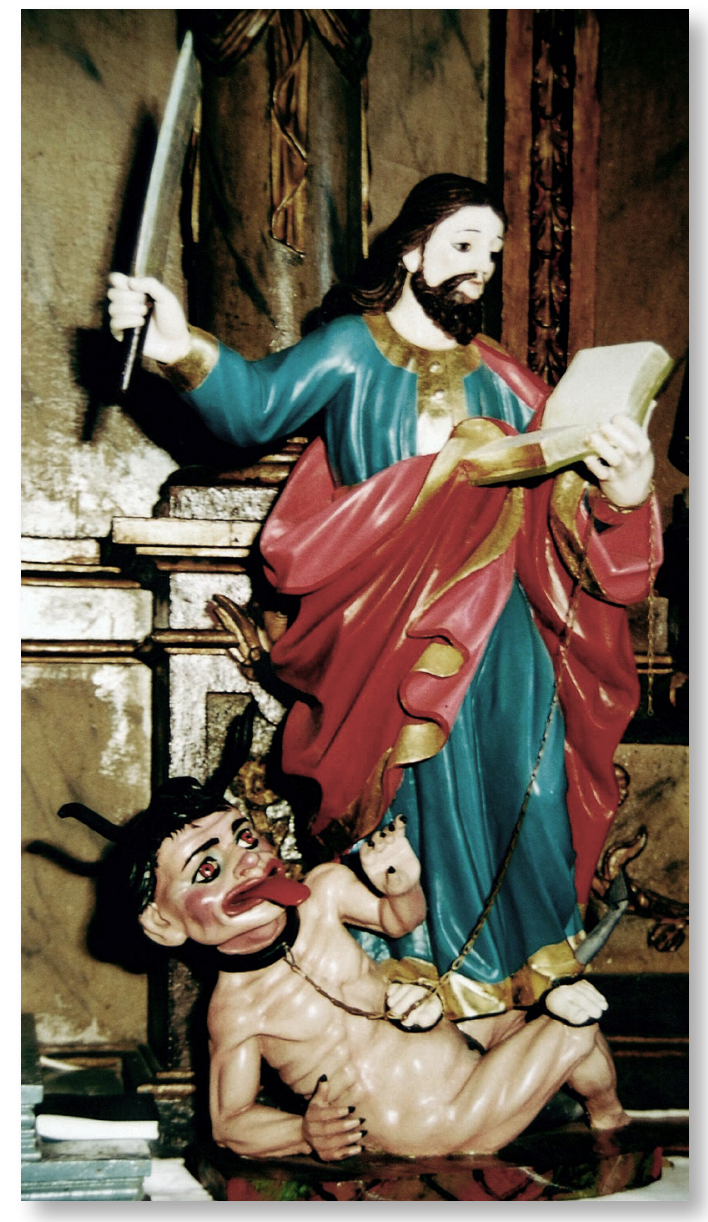

Fig. 11. Anónimo. San Bartolomé., Arzúa (A Coruña). Iglesia parroquial Santa María Castañeda

\section{DEMONIO ENVUELTO EN LLAMAS Y SU TRANSFORMA- CIÓN DE "CHAMUSCADO«" A «NEGRO»O «ETÍOPE»}

Volviendo a San Martiño Pinario, encontramos nuevamente al demonio caricaturizado en el atributo de la Virgen del Socorro [fig. 15]. Este tiene una serie de rasgos que ya conocemos: híbrido de hombre y de dragón,

pues en el Templo, donde avía de confessar sus pecados, tapiaba la boca con plomos[...] Pues, para que conozcamos, que siente Dios más el que callen en la confessión la culpa, que el delito de cometerla, lleva un Demonio a la que tiene la lengua larga; llevan dos a la que en la confesión está muda» (Damián de la Virgen, 1725: 472).

IMAGO, NÚM. 6, 20I4, 39-64 


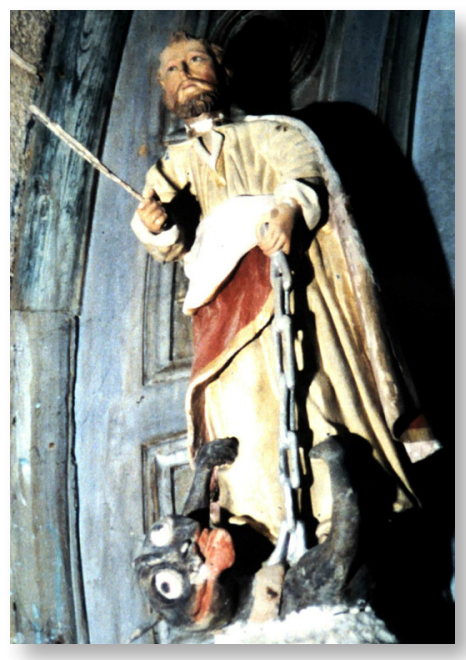

Fig. 12. Anónimo. San Bartolomé. Curtis (A Coruña). . Iglesia parroquial Santa Baia.

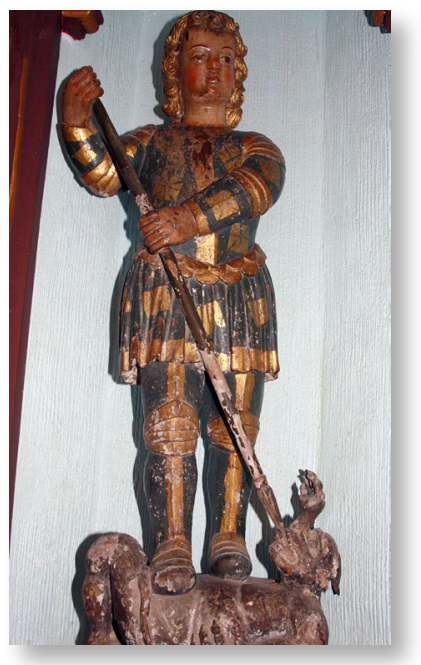

Fig. 13. Anónimo. San Miguel. Lourenzá (Lugo). Iglesia parroquial de Santo Tomé.

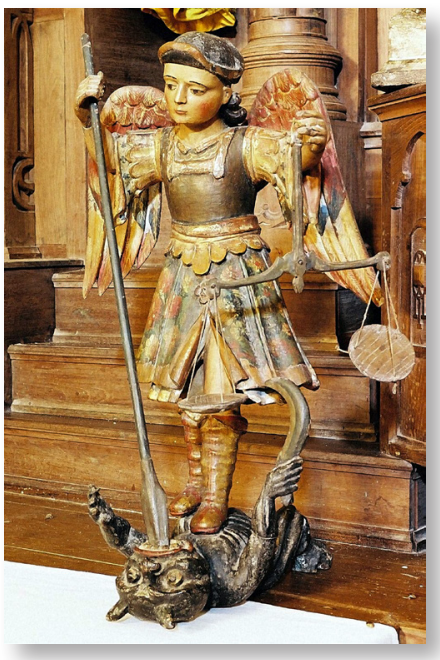

Fig. 14. Anónimo. San Miguel. Cedeira (A Coruña). Iglesia parroquial de San Fiz de Esteiro.

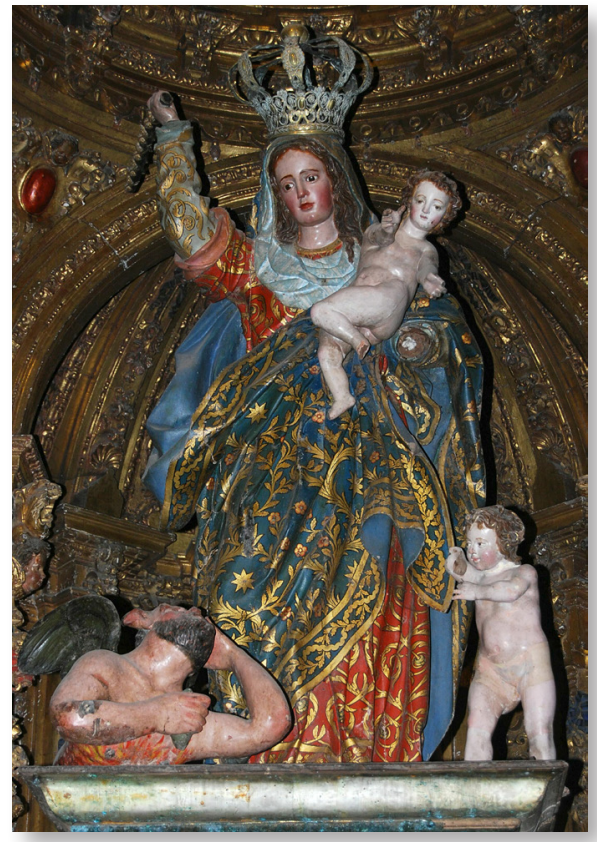

Fig. 15. Taller de Pedro de Taboada. Virgen del Socoro. Santiago de Compostela, San Martiño Pinario



Fig. 16. José Gambino. San Miguel. Santiago de Compostela. Convento del Carmen de Arriba. 


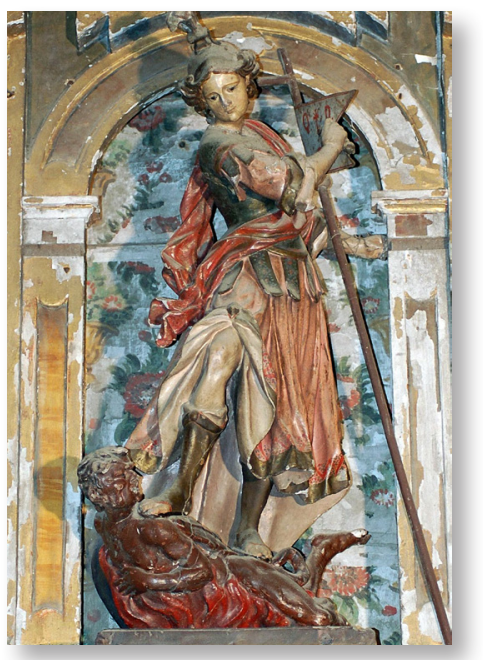

Fig. 17. José Gambino. San Miguel. Vedra (A Coruña). Iglesia parroquial de Santa Cruz de Rivadulla.

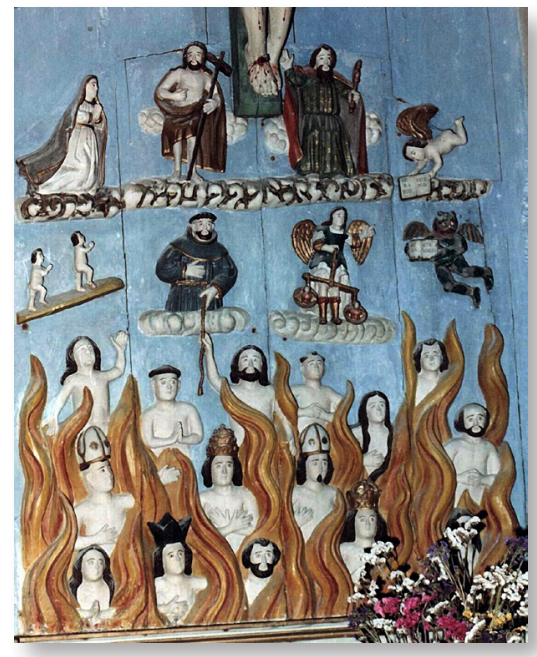

Fig. 18. Anónimo. Detalle del Retablo del Cristo de Ánimas. Cotobade (Pontevedra). Iglesia parroquial de Santiago de Viascón.

José Gambino, el mejor escultor compostelano del tercer cuarto del siglo XVIII y el creador de tipos iconográficos que perdurarán a lo largo de toda la siguiente centuria, utilizará este motivo del diablo envuelto en llamas en su iconografía de san Miguel, como podemos ver en la imagen del convento compostelano del Carmen de Arriba [fig. 16]. En la de la iglesia parroquial de Santa Cruz de Rivadulla, solar de los marqueses de tal nombre, que es la imagen más antigua del arcángel que conservamos de este autor [fig. 17], un pintor de principios del siglo xx que la repintó, cambió el pardo rojizo, por un color tostado. Sin duda, él estaba más acostumbrado a ver pintado al demonio de tal color, pues, aparte de que desde una concepción naturalista del arte, como es la decimonónica, resulta más verosímil este tono para su piel chamuscada, todavía sigue vigente el simbolismo tradicional de que la virtud es blanca y luminosa, y la maldad negra y oscura. Esto lo podemos ver claramente el retablo del Cristo de Ánimas de Santiago de Viascón [fig. 18], en que mientras el ángel blanco porta un libro con la leyenda "mira que bueno" el demonio de piel oscura y sucia lleva otro diciendo «mira 


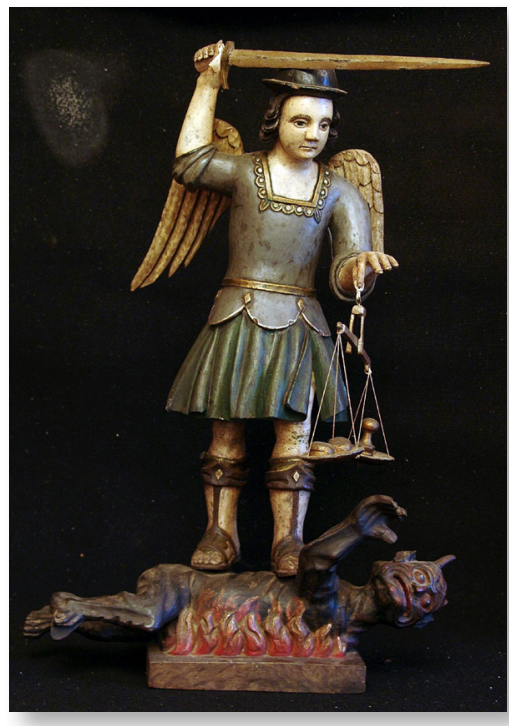

Fig. 19. Anónimo. San Miguel (Xermade). Lugo. Capilla del Santo Anxo de Buscalte.

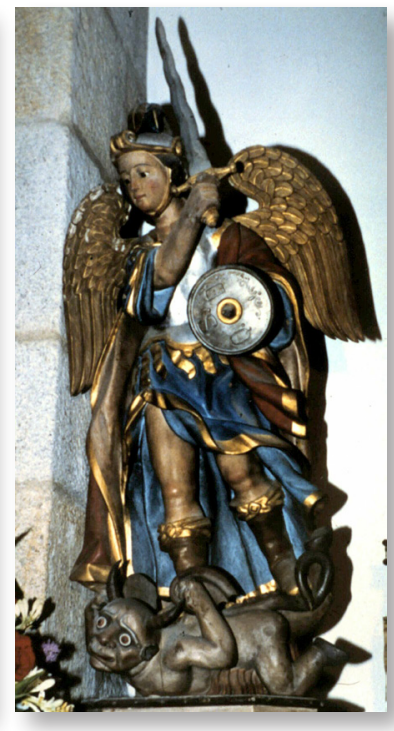

Fig. 20. Anónimo. San Miguel. Vigo. Iglesia parroquial de Santa Mariña de Cabral.

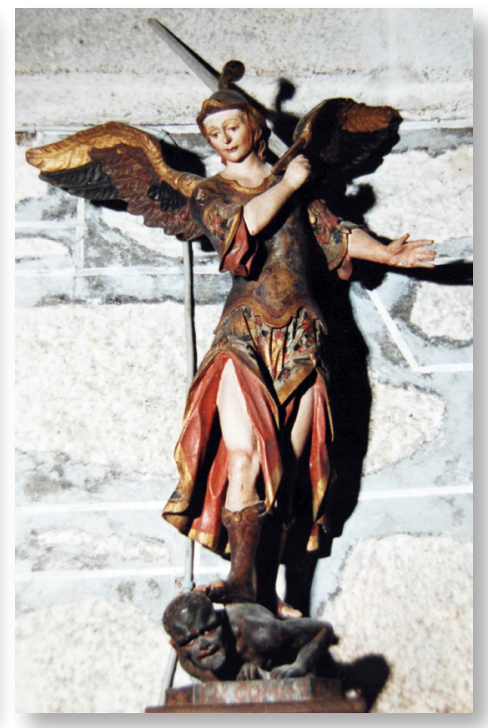

Fig. 21. Anónimo. San Miguel. Porto do Son (A Coruña). Iglesia parroquial de Santa Vicente de Noal.



Fig. 22. Anónimo. San Miguel (Gondomar). Pontevedra. Iglesia parroquial de Santa Baia de Donas. que mala»-obsérvese una vez la misoginia: hasta para las almas, la bondad es de sexo masculino y la maldad femenino-. En un principio, la negritud del demonio era un simbolismo que no tenía un componente de racial, pero que con los años, a medida que el demonio iba humanizándose y el arte haciéndose cada vez más naturalista, lo de moro o negro -etíope- de las visiones de los ascetas, se terminó imponiendo, pues al fin y al cabo "el otro" siempre da más miedo y siempre es más malvado. Pasamos así del demonio dragón humanizado, cornicabra, con orejas de asno, calvo y pelón rancio de la imagen de san Miguel de la capilla del Santo Anxo de Buscalte [fig. 19]; al calvo y pelón, con cuernos, rabo y pezuñas de toro del san Miguel de Santa Maríña de Cabral [fig. 20], hasta llegar al calvo y pelón completamente humanizado de San Vicente de Noal [fig. 21], que presenta rasgos de «etíope»; mientras que los del atributo del san Miguel de la parroquia de Santa Baia de Donas [fig. 22], son ya claramente de raza negra. Sin duda la proximidad con Portugal contribuyó a ello. 


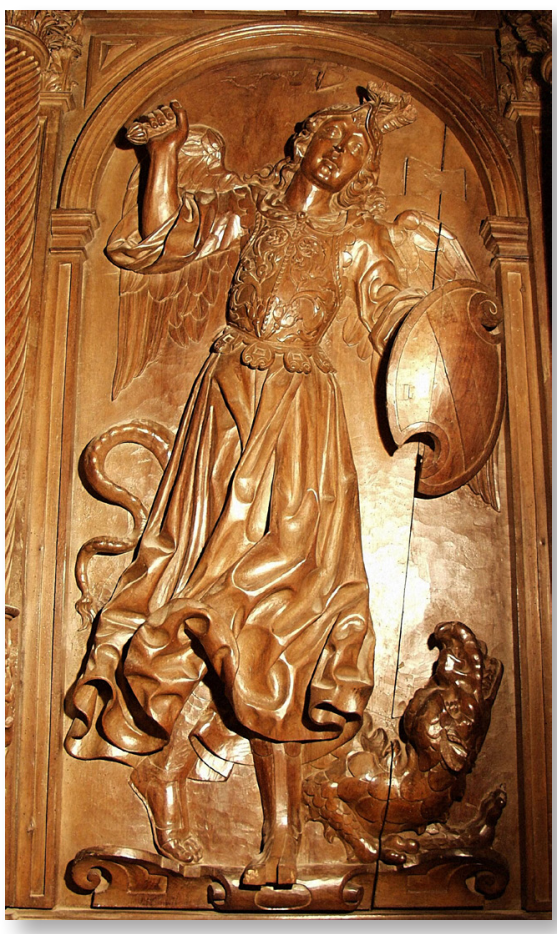

Fig. 23. Mateo de Prado. San Miguel. Santiago de Compostela, San Martiño Pinario.



Fig. 24. Mateo de Prado. Milagro de cómo san Benito desalojó al demonio de un sillar, en que estaba recostado. Santiago de Compostela, San Martiño Pinario

\section{EL DEMONIO \\ REPRESENTADO COMO DRAGÓN O MONSTRUO ${ }^{20}$ FEROZ}

También el barroco gallego representó al demonio como un dragón. Quizá los ejemplos de mejor calidad sean los del coro San Martiño Pinario -realizado por el escultor Mateo de Prado a partir del año 1639- y concretamente, los de los relieves representando a san Miguel [fig. 23] y el del «milagro de un monje que, saliendo del convento, encontró un dragón en el camino". También nuestro barroco representó al diablo como híbrido de grifo y hombre. Véase en el mismo coro, el «milagro de cómo [san Benito] desalojó al demonio de un sillar, en que estaba recostado" [fig. 24]. Sin embargo, en el barroco compostelano, el diablo no se representa en forma de bestia horrible y feroz. Sin duda, la mejor representación de la escultura gallega bajo tal apariencia, sea la del demonio de la imagen de san Bartolomé [fig. 25] que Francisco de Moure, realizó para la feligresía orensana de Santa María de Beade, en los primeros años del XVII. Muy posiblemente, el vino del lugar: el ribero, había inspirado al escultor. Al fin y al cabo, el santo es en esta tierra el patrón de los viticultores ${ }^{21}$.

Moure lo figura mezclando rasgos de esfinge y grifo. De la primera toma el cuerpo

20. «Parto u producción contra el orden regular de la naturaleza. Viene del Latino Monstrum. NIEREMB. Philos. curios. lib. 3. Juntas de animales de diversa naturaleza, causan también admirables monstruos» (Dic. Aut.). 21. Agradezco el dato a José Manuel García Iglesias.

IMAGO, NÚM. 6, 20I4, 39-64 




Fig. 25. Francisco de Moure, San Bartolomé. Beade (Ourense). Iglesia parroquial de Santa María.

de león con unos grandes pechos femeninos -aunque los suyos sean flácidos y no densos, como los que tiene el demonio pelón y capón, atributo de san Miguel en la cruz parroquial de San Martiño de Visantoña [fig. 26]-, pero su cabeza, ya no es de mujer, como en la esfinge clásica, sino que combina facciones de león -en las que destaca una feroz boca, repleta de dientes de sierra en la mandíbula inferior ${ }^{22}-$, con las de grifo: nariz aguileña y ganchuda, mentón prominente y frente muy inclinada hacia atrás. Su piel es pardo rojiza, pero tiene rojos los ojos y también la punta de las fosas nasales. Posee, además, una enorme cornamenta doble: de cabra que le nace en la parte superior de cabeza y de macho cabrío que le surge sobre las sienes. Esta última se enrolla dando una vuelta sobre sí misma y -como



Fig. 26. Anónimo. San Miguel, detalle cruz parroquial (Mesia) A Coruña. San Martiño de Visantoña.

diría Quevedo de ciertos bigotes- sirviendo de guardamanos a unas orejas de asno caídas. De sus antebrazos brotan púas, que son más tejas de dragón que plumas de grifo. Con la mano derecha le está haciendo una figa a san Bartolomé, mientras que con la izquierda le pone los cuernos. Teniendo en cuenta que san Bartolomé desterró la ignorancia cuando hizo que:

el mismo demonio Astarot, que ellos engañados adoravan y tenían por verdadero Dios, confesasse sus mentiras y engaños, con las quales traía embaucado y perdido al pueblo. Y assí estando el Rey presente en el Templo, y los sacerdotes y mucha gente que avía concurrido a ver este espectáculo, el demonio, por mandato de san Bartolomé confesó y declaró los embustes y artificios que solía usar, y que él no era Dios, antes

22. Recordemos que según san Pedro es un león furioso y, de hecho, Moure lo representará así en los laterales del Retablo Mayor del Colegio del Cardenal de Monforte. 
estava atado con cadenas de fuego por los Ángeles del verdadero Dios (Rivadeneyra, 1616: 590).

Vemos lógico que Moure utilice para representar en este caso al demonio un remedo de esfinge, pues esta simboliza tradicionalmente la ignorancia. La cual es la que propicia que el demonio utilice sus principales armas, que, aparte de la lujuria -también simbolizada por propia esfinge como lo evidencian las tentaciones a san Alberto (José de Santa Teresa, 1678: 399) y a santo Toribio (Guerrero Martínez Rubio, 1728: 167)-, son la soberbia -de la que ya hemos dicho que Molanus la simbolizada en los cuernos de macho cabrío- y la envidia, que es la que el demonio le tiene al hombre ${ }^{23}$. Precisamente la ignorancia y envidia, se hacen obvias a través de los gestos supersticiosos que inútilmente el demonio dirige a san Bartolomé, poniéndole los cuernos y la higa, pues con estos más que insultarlo, llamándole consentidor, quiere evitar su mal de ojo, creyendo que, como a él, la pasión que le mueve es la envidia y, por consiguiente, trata de protegerse de ella con los mismos gestos con que los hombres intentan prevenirse de él. De estas creencias supersticiosas se ríe Teresa de Jesús, al tiempo que las denuncia, cuando dice: "y una higa para todos los demonios, que ellos me temerán a mí. No entiendo estos miedos, demonio, demonio, donde podemos dezir Dios, Dios y hazerle temblar. Si que ya sabemos que no se puede menear, si el señor no lo permite» (Teresa de Jesús, 1674: 190).

Al fin y al cabo el demonio, como envidioso que es, no hizo otra cosa que hacerse mal a sí mismo y como la esfinge clásica terminó despeñado a causa de su ira -recordemos los ojos y las fosas nasales enrojecidos-. Aunque como es sabido, en la historia de

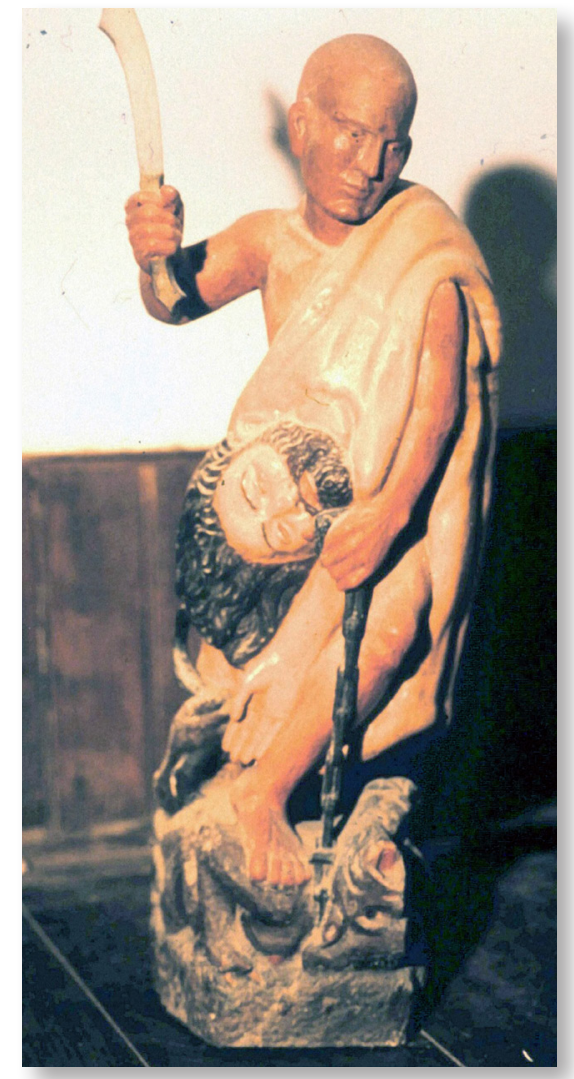

Fig. 27. Anónimo. San Bartolomé. Culleredo (A Coruña). Iglesia parroquial de San Estevo.

san Bartolomé, el demonio, se tomaría su revancha, haciendo que el rey del territorio colindante, instigado por Astarot y sus sacerdotes, mandará desollar al apóstol (Rivadeneyra, 1616: 591). Hete aquí, porque Moure lo representa a medio despellejar, pero en san Estevo de Culleredo [fig. 27] lo podemos ver ya completamente desollado. Ello hará que haya quien crea que el apóstol era calvo, cuando sabemos ciertamente que no lo era, por el fehaciente testimonio dado por del demonio Berit, que lo describe como: «un hombre que tenía los cabe-

23. «el Padre San Agustín[dice]: ‘Aparte Dios la peste de la envidia de los ánimos de todos. La envidia es vicio diabólico, del qual es reo el demonio, y no solo reo, sino reo sin disculpa. No fue condenado porque cometió adulterio, porqué robó. porque usurpó la posesión de alguno; sino porque al hombre, que estaba firme, le envidió, luego que cayó de su firmeza'» (Quevedo, 1790: 22).

IMAGO, NÚM. 6, 20I4, 39-64 


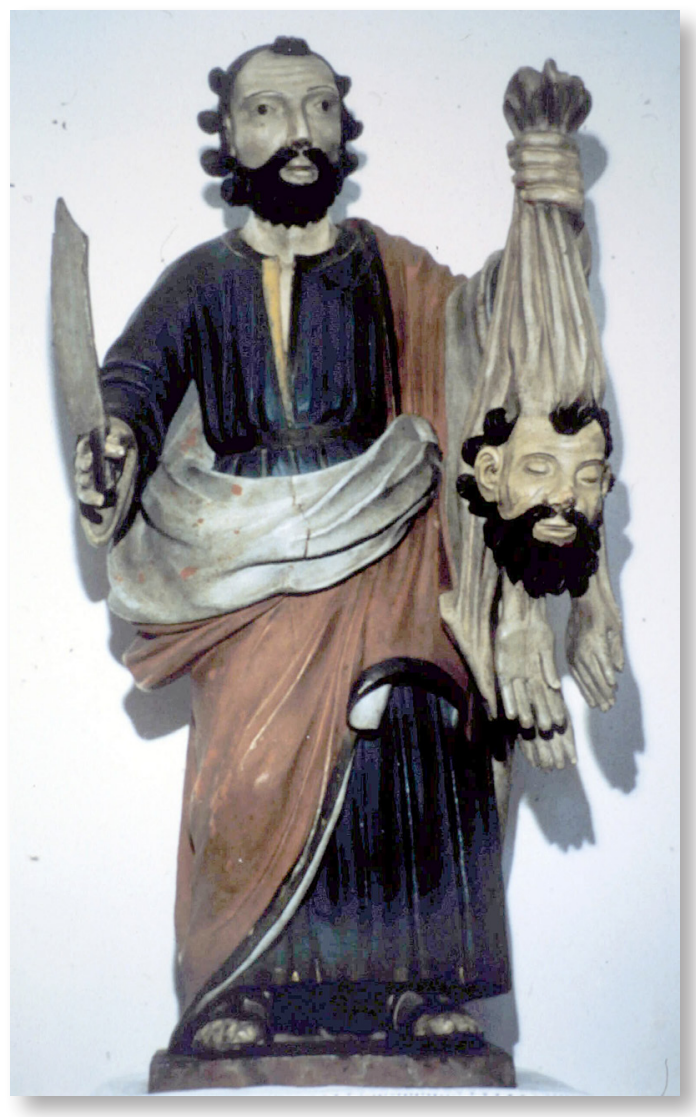

Fig. 28. Anónimo. San Bartolomé. Pontedeume (A Coruña). Iglesia parroquial de Santiago de Boebre.

llos negros y crespos, el rostro blanco, los ojos grandes, las narices iguales y derechas, la barba larga y entrecana; la estatura mediana, los vestidos blancos, y que no se le envejecían porque en veintiséis años nos las había mudado» (Ribadeneyra, 1616: 590). Y de hecho en la imagen vemos que la piel, que el apóstol voltea sobre su hombro izquierdo, tiene pelo y barba. En Santiago de Boebre [fig. 28] hay una representación suya mucho menos incruenta, pues se le representa mostrando su piel, pero él está sin despellejar.

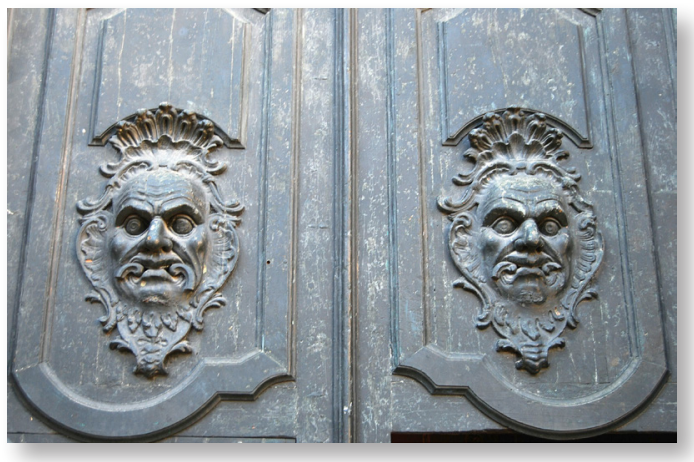

Fig. 29. Atribuido a José Gambino. Demonios con la lengua atada con una argolla. Santiago de Compostela, San Martiño Pinario.

\section{AVISOS PARA QUE EL FIEL SEA HUMILDE Y RENUNCIE AL MUNDO Y A SUS VANIDADES}

Como señala Pedro de Valderrama, las esfinges también se solían poner a la entrada de los templos, para recordarle a los hombres que debían entrar a ellos humildes, dejando fuera toda la curiosidad y la necia sabiduría mundana a la que alcanza su entendimiento, pues ellos solo podrán entender los misterios divinos, si el propio Dios quiere desvelárselos (Valderrama, 1608: 3637). Una función similar deberían tener los dos mascarones, atribuibles a José Gambino ca.1771, que encontramos en las puertas de la iglesia de San Martíño Pinario [fig. 29], figurando a sendos demonios con la lengua atada por una argolla. Pues ellos son un recuerdo para que el fiel que penetre en el templo, no se envanezca de su sabiduría terrena queriendo entender los misterios divinos, ni eche la culpa a Dios de sus desgracias y, por el contrario, se dé cuenta de su propia debilidad y se humille -no literalmente, como lo acaba de hacer descendiendo por las escaleras que conducen a la entrada del templo, sino espiritualmente-, reconociendo que solo Dios es capaz de atarle la lengua al demonio, y que, incluso, Él, para hacerlo, tuvo, sin tener culpa alguna, que sufrir y padecer el tormento de la cruz: 
Poníale Job a Dios muchos argumentos, y para hazerlo callar le Dixo, cap. 40 An extrahere pateris Leviattaham hamo, $\theta$ fune ligabus linguam eius? Donde debaxo de la metáfora de aquel dragón marino, habla Dios del Demonio, con el qual quiso hazer este argumento a Job: ¿Podrás tu con tu anzuelo pescar al demonio, y atalle la lengua, y darle en ella un nudo, para que no la pueda rodear en la boca? fue dezir más claramente: Podrás tu hazer callar al demonio, que es hablador de ventaja y podrás tu hallar algunas razones tan fuertes, que se la añuden como soga, para que se enfrene y no tenga que responder a lo que yo dixere? Pues si tú no puedes hazer esso, sábete que yo puedo, porque yo tengo anzuelo con que pescarlo y con el mismo cordel del anzuelo ataré la lengua para que no hable, con lo qual quiso dezir a Job: No os pongays conmigo a razones, ni se ponga conmigo el hombre en argumentos, que pues yo hago callar al demonio, y tengo con que atarle la boca, también os haré callar a vos, que en su respeto no sabeys hablar, por más ladino que seays: pero ay aquí una agudeza escondido muy estraña, la qual nos descubrió el gran Anastasio, como refiere san Anastasio en su vida: el cual llamó a la Cruz de Cristo, anzuelo con que pescó al demonio assi dize él: Con el anzuelo de la Cruz pescó al demonio, y con el cordel esse mismo anzuelo, le ató la lengua: porque en sabiendo que Dios murió en la cruz no hay que hablar, ni tiene ya que hablar el demonio, ni en materia de Imperio, ni en materia de dificultades, de lo que Dios nos quiere. Y aun por ventura esto le quisieron dezir a Job: Que andas hablando mucho, diziendo que padezes sin culpa, y poniendo argumentos, de si quiero a los hombres, o no los quiero, al demonio he de hazer callar con la Cruz, y con lo que por los hombres he de padecer: y con essa misma Cruz mía te quiero hazer callar a ti, y atarte la lengua, pues no has padecido tu

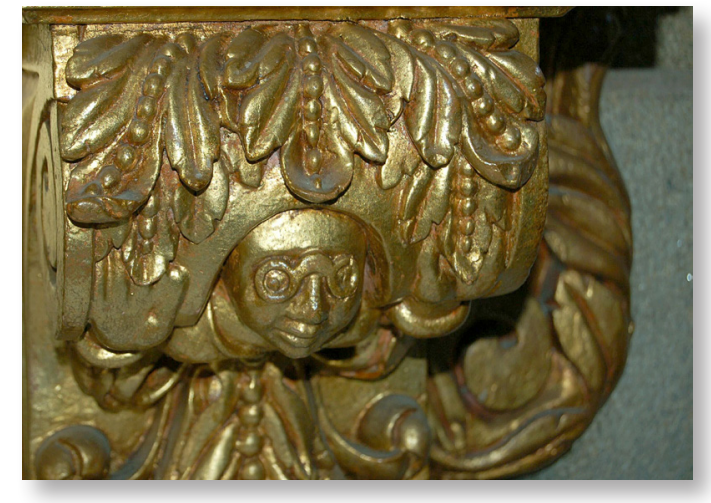

Fig. 30. Anónimo. Cabezas con antojos. Detalle del Retablo de San Andrés Santiago de Compostela, Santa María Salomé.

en tu muladar tanto como yo padeceré en la Cruz, ni tan sin culpa (Aunque más te justifiques) como me pondrán a mí en ella (Valderrama, 1608: 36-37).

Estamos, por consiguiente, ante un mensaje que no puede ser más neoestoico. Se le dice al fiel: recuerda que no eres nada, que no vales nada, y que tu única salvación reside en humillarte, sujetándote a la voluntad divina.

Otro mensaje neoestoico, aleccionando al creyente para que renuncie al mundo y a sus vanidades, lo encontramos en las cabecillas con gafas [fig. 30] de los machones del retablo de san Andrés [fig. 31] de la Parroquia compostelana de Santa María Salomé, pues ellas le están recordando que él, a causa de su naturaleza humana, padece estrabismo y que por más anteojos que se ponga, lo único que conseguirá es acrecentar el tamaño de los antojos ${ }^{24}$ con los que el demonio le tienta, atravesándose cada vez más en su camino hacia el cielo. Por ello, si quiere alcanzar este, lo único que le cabe es

\begin{abstract}
24. Gracián juega continuamente con la dilogía de antojo: «muchos por tener antojos, no ven» en este mundo que "todo anda al revés y todo trocado de alto abaxo» (Baltasar GRACIÁN, 1984, 591-592). Por eso, en El Criticón, los "antojos» se venden en la calle de los mercaderes engañadores que tienen sus tiendas en la calle del Artificio: (Baltasar Gracián, 1984, 163). Por otra parte, decir que la utilización del anteojo con este significado es muy frecuente en la emblemática española. Lo encontramos en Borja: Sic animi affectus (Juan de Borja, 1680, 92-93), en Sebastián de Covarrubias: Sombras son de la Verdad (Sebastian de Covarrubias, 1610, 18) y con la variante del catalejo en Saavedra Fajardo: Affectibus crescunt decrescun (Diego Saavedra Faxardo, 1724, 36-37).
\end{abstract}

IMAGO, NÚM. 6, 2014, 39-64 


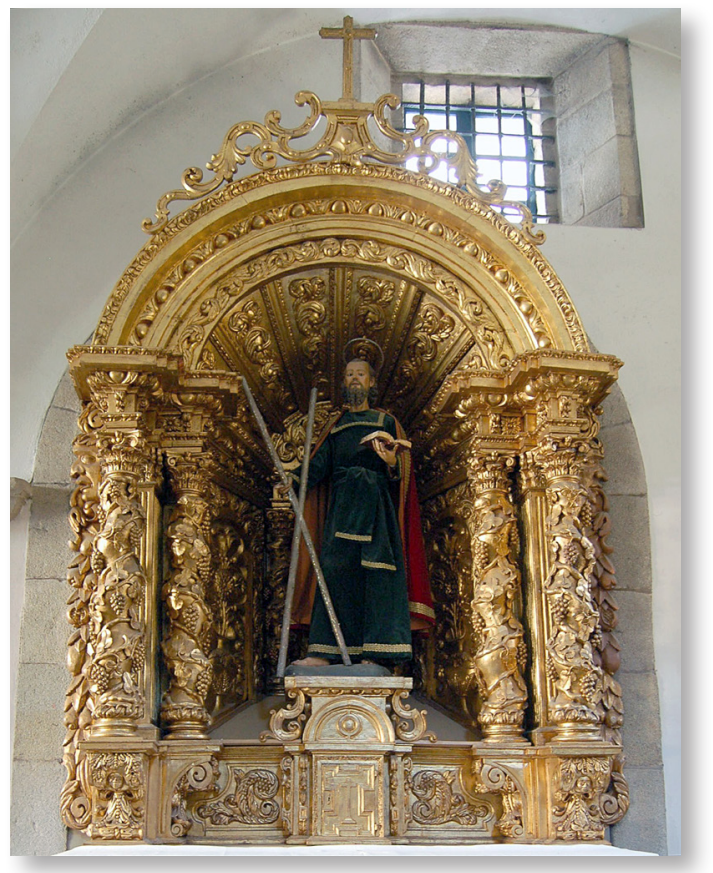

Fig. 31. Anónimo. Retablo de San Andrés. Santiago de Compostela, Santa María Salomé.

renunciar al cuerpo y sus pasiones y ver solo con los ojos del espíritu. Se le dice así al fiel, que su vida no es esta finita del mundo, sino la eterna que da la fe de Jesucristo que confiesa san Andrés ${ }^{25}$ y que si quiere conseguirla debe coger la cruz que Dios le da, no solo



Fig. 32. Mateo de Prado. Misericordia. Detalle del Coro. Santiago de Compostela, San Martiño Pinario. sufriéndola con constancia y paciencia, sino incluso buscándola con alegría, como hizo él, que "por el amor, que a Christo Nuestro Señor tenía, quando vio la cruz en que había de ser muerto, se llenó tanto de gozo, que empezó a decirla mil ternuras y palabras cariñosas» (Barón y Arin, 1742: 124).

\section{"ACOGERSE A SAGRADO" NO VALE PARA ESTAR LIBRE DEL DEMONIO}

Y una vez dentro del templo, no piense el fiel que está a salvo del demonio, pues «el acogerse a sagrado" vale para las persecuciones de la justicia civil, pero no en la lucha contra el demonio, quien lo combatirá, en todo lugar y en todo tiempo y fuere cual fuere su estado, y, precisamente, no guardar el decoro requerido al espacio sagrado o a la propia devoción exigida en la oración, puede incrementar todavía más la ofensa a Dios, lo que es aprovechado por el demonio para echar sus redes. Félix de Alamín previene contra ello contando la historias como la del demonio disfrazado de etíope:

\begin{abstract}
La causa del sueño es el demonio que le procura traer, y assí refiere que un religioso estando en oración con otros religiosos vio entrar al demonio en figura de un Etíope que traía bancos sobre los hombros y los iba ofreciendo a cada uno, y algunos no les querían admitir, y los religiosos que los admitían luego se quedaban dormidos (Alamin: 1714, 159).
\end{abstract}

Por eso, en el propio coro, el monje que baja o levanta su asiento, observará figurada en su misericordia una caratula demoniaca o, incluso, un capón pelón [fig. 32], que le recordará que el propio demonio es quien coloca banquitos en tal lugar, para que se

25. Recordemos que este apóstol se asocia al artículo del credo: et in Iesum Christum filium eius unicum. 


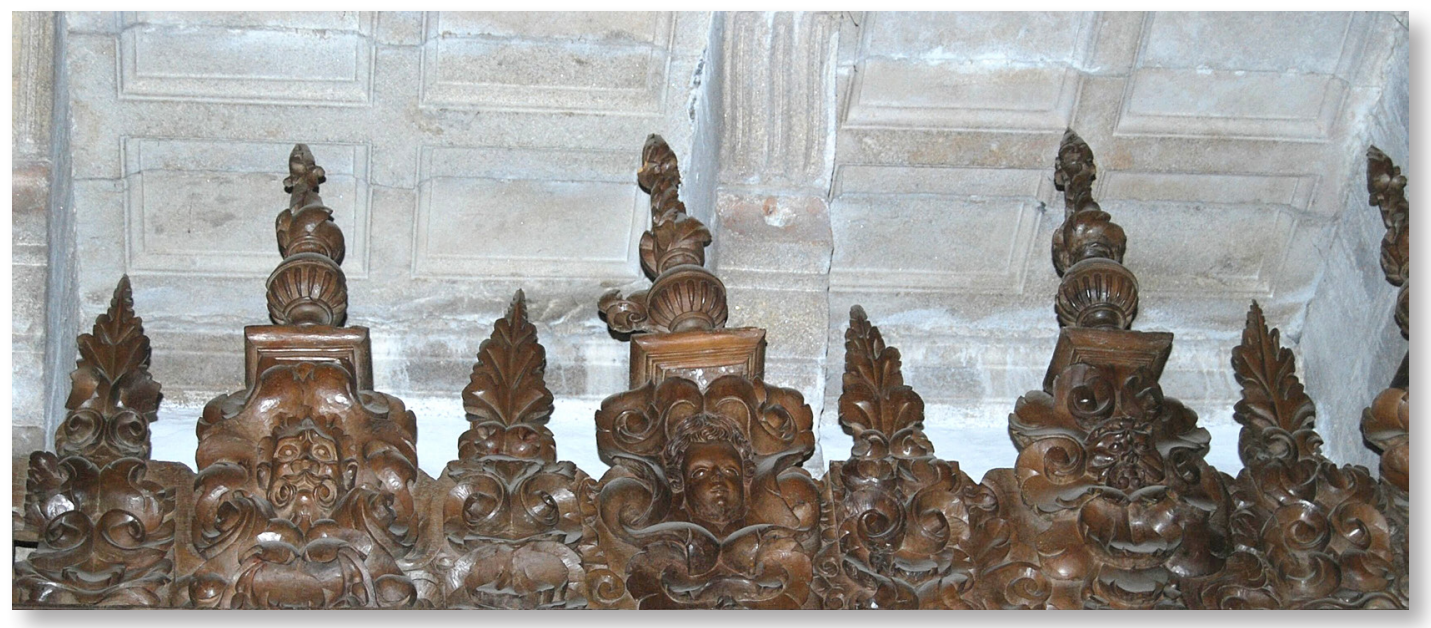

Fig. 33. Anónimo. Crestería del Coro. Santiago de Compostela, San Martiño Pinario.

acomode, y prescinda de la devoción que exige la oración. Como también en la crestería que corona el coro, puede ver figuras quiméricas y niños [fig. 33], que le alertan para que no se distraiga con pensamientos vanos. Hemos de reconocer que estas son recomendaciones muy sutiles, comparadas con otras que encontramos en la literatura monástica, dignas de fray Gerundio, como la que cuenta Jaime Barón de un monje:

que frecuentemente rezaba medio durmiendo y cabeceando y muchas veces del todo dormía, quando los otros rezaban. ¡Caso formidable! La imagen de un Santo Cristo, que en el cuarto estaba, se llegó a él, y desenclavando una mano le dio con ella tan recia bofetada, que lo arrojó en tierra, y al tercero día murió del golpe (Barón y Arín, 1732: 57).

\section{CODA}

Consecuentemente, la escultura barroca compostelano le está recordando constantemente al fiel, que, como san Miguel, se haga la pregunta esencial para alcanzar la vida del espíritu: ¿Quién como Dios? y no se deje engañar, como el pintor decimonónico que, instruido por un sacerdote ignorante, repintó la imagen del patrono de San

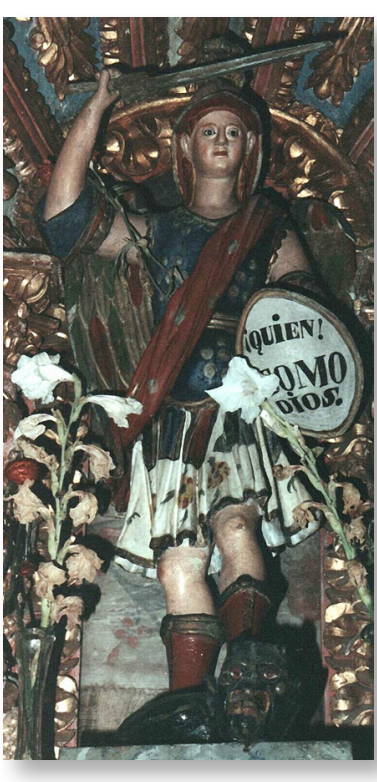

Fig. 34. Anónimo. San Miguel. Forcarei (Pontevedra). Iglesia parroquial de San Miguel de Presqueiras.

Miguel de Presqueiras [fig. 34], y convirtió el nombre del arcángel, Miguel, esto es: ¿quién como Dios?, en una máxima mundana al escribir entre signos de de admiración ¡QUIEN! y concluir con un modo de vida autocomplaciente: COMO DIOS. Por algo, los estoicos, y el refranero popular, nos avisan siempre que «de la admiración, la ignorancia nació». 


\section{BIBLIOGRAFÍA}

Alcuino. [1795]. Homiliario o Colección de Homilías, o Sermones de los más excelentes santos padres $y$ doctores de la iglesia, sobre los evangelios, que se cantan en las principales festividades, y tiempos del año, recopiladas por el doctor Alcuino, maestro del emperador Carlo Magno: Traducidas al Castellano por el Bachiller Juan de Molina, Madrid, Benito Cano.

Aguado, F. [1629]. Tomo Primero del perfecto religioso, Madrid, Viuda de Alonso Martín.

Alamín, Fr. F. DE. [1714]. Falacias del demonio $y$ de los vicios, que apartan del camino real del cielo, en que se descubren muchos engaños del demonio, con que oculta los caminos verdaderos, y propone falsos, y sus remedios generales y particulares. De nuevo se han añadido las consideraciones de los novísimos, $y$ de la Passión del Salvador, los vicios de la lengua, y las virtudes principales en qué consiste la perfección Christiana común a todos y aún los vicios aora van mucho más declarados. Preserva contra los errores de Molinos, Preserva de enfermedades, y enseña el modo de alarga la vida según el modo natural. Es obra utilísima para quien desea conocer los engaños de Satanás, y librarse de sus lazos, como lo declara el Prólogo, y para que esto se conozca bien puede el Autor se lea el Cap. I del tract. 5., fol.223 y después el prólogo. Dedicase al Primer Ministro de Dios, Príncipe de los Ángeles, Protector del Pueblo escogido de Dios, San Miguel Arcángel, Madrid, Imprenta de Blas de Villanueva.

BARÓN Y ARÍn, J. [1732]. Remedio Universal de todas las necesidades y trabajos, El Rosario

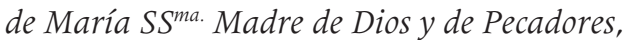
Zaragoza, Luis de Cueto.
BARÓN y ARÍN, J. [1742]. Luz de la Fe, y de la Ley, entretenimiento Christiano entre Desiderio, y Electo, Maestro, y Discípulo, en Diálogo, y Estilo Parabólico, adornado con varias historias, y moralidades para enseñanza de ignorantes en la doctrina Christina, Madrid, Antonio Sanz.

Borja, J. de [1680]. Empresas Morales Brusselas, Francisco Foppens, Impressor y Mercader de Libros.

Cienfuegos, A. [1726]. La Heroyca vida, virtudes, y milagros del grande san Francisco de Borja, antes duque quarto de Gandía y después Tercero General de la Compañía de Jesús, Tercera Impresión, Madrid, Bernardo Peralta.

COVARRUBIAS, S. DE [1610.]. Emblemas Morales, Madrid, Luis Sánchez.

DAMIÁN DE LA VIRGEN [1725]. Bendita sea la Santíssima Trinidad. Ave María. Tomo segundo de las Quaresmas [de las tres ferias mayores]. Zaragoza. Pedro Carreras.

GRACIÁN, B. [1984]. El Criticón, Santos Alonso (ed.), Madrid, Cátedra.

GRANADA, FR. LUIS DE. [1584]. Primera Parte de la introduction del symbolo de la Fe, en la qual se trata de la creación del Mundo para venir por las Criaturas conoscimiento del Criador $y$ de sus divinas perfectiones, Barcelona, Pablo Manescal, Damián Bages y Hierónimo Genovés, .

Guerrero Martínez Rubio, N. A. [1728]. El Phénix de las becas, Santo Toribio Alphonso Mogrobejo, hoguera de sus virtudes celebradas por su colegio mayor de San Salvador de oviedo, de su deseada canonización le dedicó amante en el mes de julio del año pasado de 1727, Oviedo, Viuda de Gregorio Ortiz Gallardo y E. Garcia Honorato y san Miguel. 
Hablemos de ángeles calvos, demonios pelones y figuras grotescas en la escultura barroca gallega

Hidalgo, Gaspar L. [1610]. Diálogos de apacible entretenimiento, que contiene unas Carnestolendas en Castilla. Dividido en tres noches, del Domingo, Lunes y Martes de Antruexo, Procura el autor en este libro entretener al Letor con varias curiosidades de gusto, materia permitida, para recrear penosos cuydados a todo género de gente, Brusselas, Roger Vulpuis.

InTERIAN De AyAlA, J. [1782]. El Pintor Christiano y erudito, o tratado que suelen cometerse frecuentemente en pintar y esculpir las Imágenes Sagradas Dividido en ocho libros con un apéndice. Obra útil para los que se dedican al estudio de la Sagrada Escritura, y de la Historia Eclesiástica Escrita en Latín por [...] y traducida en Castellano Por D, Luis de Durán y de Bastero, Madrid, Joaquín Ibarra, Impresor de Cámara de S.M.

José DE SANTA TERESA. [1678]. Flores del Carmelo. Vidas de los santos de Nuestra Señora del Carmen, que reza su Religión, así en común, como en particulares conventos, Madrid, Antonio Gonçalez de Reyes.

López CALderón, M. [2009]. Lenguaje, estilo y modo en la escultura de Francisco de Moure y José Gambino, Santiago, Universidad de Santiago de Compostela.

Molanus, J. [1771]. De Historia SS. Imaginum et Picturarum pro vero earum usu contra abusus, Libri Quator, Lovanii, Typis Academicis.

NAVARRO, G. [1631]. Tribunal de Superstición Ladina, explorador del saber, astucia y poder del Demonio; en que se condena lo que suele correr por bueno de Hechizos, Agüeros, Ensalmos, vanos Saludadores, Maleficios, Conjuros, Arte notoria, Cavalista, Y Paulina, y semejantes acciones vulgares, Huesca, Pedro Bluson.

NÚÑEZ DE GUZMÁN, H. [1555]. Refranes, o Proverbios en romance, Salamanca, Iuan de Canova.
PACHeco, B. [1611], Espejo de sacerdotes y de todos los ministros de la hierarchia eclesiastica, Madrid, Luis Sánchez

PinedA, J. DE. [1606]. Segunda Parte de la Monarchía Ecclesiástica, o Historia Universal del Mundo, Barcelona, Iayme Cendrat.

Puente, J. DE LA. [1612]. La conveniencia de las dos monarquías católicas, la de la Iglesia Romana y la del Imperio español, Madrid, Imprenta Real.

QueVedo Y VillegAs, F. DE. [1790]. Obras, Tomo V., Madrid, Antonio Sancha.

QueVedo y VillegAs, F. DE. [1987]. La Hora de todos y la Fortuna con seso, (edición de Jean Bourg, Pierre Dupont y Pierre Geneste), Madrid, ediciones Cátedra S.A.

Quevedo y Villegas, F. DE. [1993]. Prosa Festiva Completa, Celsa Carmen GarcíaValdés (ed.), Madrid, ediciones Cátedra S.A.

RIVADENEYRA, P. DE. [1616]. Flos Sanctorum. Libro de la vida de los Santos, Madrid, Luis Sánchez.

SAAVEDRA FAJARDO, D. [1724]. Idea de un Príncipe Político y Christiano, representada en cien Empresas, Madrid, Francisco Laso.

SARACHO, FR. J. DE. [1736]. Jardín de Flores de la Gracia. Escuela de la mejor doctrina. Vida y Virtudes de la prodigiosa y venerable señora doña Antonia Jacinta de Navarra y de la Cueva, Abadesa del ilustrísimo y Real Monasterio de las Huelgas, cerca de Burgos, del Orden del Glorioso y Melifluo Padre San Bernardo, Burgos, Athanasio Figueroa.

TERESA DE JESÚs. [1674]. Obras de la gloriosa madre Santa Teresa de Jesús, fundadora de la reforma de la orden de nuestra señora del Carmen de la primera observancia, Tomo Primero, Brusselas, Francisco Foppens Impressor y Mercader.

TERreros PANDo, E. [1787]. Diccionario castellano con las voces de ciencias y artes y sus correspondientes de las lenguas, francesa, latina e italiana ,T. II, Madrid, Imprenta de la Viuda e Ibarra, Hijos y Compañía. 
TORRES, L. DE. [1607]. Veyntiquatro discursos sobre los pecados de la lengua, y como se distinguen, y de la gravedad de cada uno de ellos. Barcelona, Sebastián de Cormellas.

TORRes Villarroel, D. DE. [1794]. Sueños morales, visiones y visitas que con D. Francisco de Quevedo por Madrid, Barca de Aqueronte, y residencia infernal de Plutón. t. .II, Madrid, Imprenta de la Viuda de Ibarra.

VAlDERRAMA, P. DE. [1608]. Primera segunda y tercera parte de los exercicios espirituales para todas las festividades de los santos aora de nuevo emendado, Madrid, Alonso Martin.
VEGA, FR. M. DE LA. [1647]. Discursos predicables sobre todos los evangelios, Dominicas, Ferias, Quartas, Sextas y toda la Semana Santa, con Índice y Elencho para todas las fiestas de el Año, Granada, Antonio René de Lazcano.

ZEVALLOS, L. I. [1733]. Vida y virtudes, favores del Cielo, milagros y prodigios de la V.M. Sor María Ángela Astorch capuchina, Natural de Barcelona, Fundadora en Murcia de su Ilustre Convento de Capuchinas, de la Exaltación del Santíssimo Sacramento, Madrid, Imprenta de Gerónimo Roxo. 